\title{
What Did Aid Administrators Perceive to Be the Impact of PPY on Students and Aid Offices?
}

By

Valerie A. Mockus, University of South Florida

T hrough the 2016-2017 academic year, student aid applicants completing the Free Application for Federal Student Aid used the immediately previous year's tax information. Beginning in 2017-2018, students were required to use two-year-old tax return information creating a lag in the timeliness of financial health data used to calculate financial aid eligibility. This older data is called Prior-Prior Year (PPY) by the aid community.

Community members in support of the change expected college applicants to have more time to apply for aid and make decisions.

Others articulated concerns that use of the older data would increase the likelihood of families requesting professional judgements (manually intensive calculations with more recent tax data), therefore significantly increasing the workload. Early detractors worried the older tax data would erode the accuracy of targeting aid to the right students.

This pilot phenomenological study investigates how financial aid administrators perceive the impact of the switch to PPY on students and financial aid offices. The study finds that the volume of professional judgements did not appear to increase, the Department of Education's choice to re-ask for 2016 tax information and penalize students with discrepancies by withholding aid disbursements was objectionable, the administrative burden was worrisome, and college affordability was of great concern. It also finds that administrators, though never coming to a career financial aid intentionally, find their work deeply meaningful notwithstanding.

Though the expected issue of an increased volume of PJs did not materialize, there was an unexpected issue of complying with comment code 399 requirements that arose, likely due to the Department of Education's choice to not consult financial aid administrators during the design and implementation of PPY. As the first phenomenological study on PPY, this article provides administrators and researchers alike with insight into opportunities for improvement in future FAFSA changes.

Keywords: Student Financial Aid, FAFSA, Prior-Prior Year

Copyright ( 2019 , Valerie A. Mockus. This article is published under a Creative Commons BY-NC license. Permission is granted to copy and distribute this article for non-commercial purposes, in both printed and electronic formats 


\section{Introduction}

In preparation for the 2017-2018 school year, the United States Department of Education implemented a change to the collection of tax information for families completing the Free Application for Federal Student Aid (FAFSA). (See the appendix for entire application.) The change required families to use tax information from the second preceding tax year. In all previous years of federal student aid, families applying for financial aid were required to use the income information from the immediately preceding year.

The option of using two-year old tax data has been discussed in the profession of financial aid for over two decades as a possible way to help families, especially those filing late in the spring and filing tax return extensions-often missing aid application deadlines. In 2008, the federal government passed the Higher Education Opportunity Act which allowed for adoption of prior-prior year tax usage. In 2015, President Obama declared changes to the procedures for processing financial aid allowing for use of the Prior-Prior Year (PPY) income information in the federal aid application process (The White House, 2015).

The new initiative came with some challenges. Aid officers did not anticipate the challenges created by the federal government application logistics. Instead of offering skip logic, families of returning students were expected to complete both 2016-2017 and 20172018 with the same tax year information. Students and families, when completing the FAFSA, often did not know how to answer the questions or did not recall the exact amounts so they used guesstimated and rounded values. The result was conflicting information between the years for students who completed FAFSAs during both years. Those discrepancies were assigned a code of 399 on the FAFSAs sent to colleges and universities and had at least two negative impacts.

First, students with a conflict between years were denied their subsequent financial aid disbursements until the conflict was resolved (Federal Student Aid (FSA), 2016a). For many current college students, this meant no federal financial aid at the start of the spring term as the new earliest application date was moved to October 1. This allowed 3 months more collection than in the previous years where January 1 was the earliest application date. Effectively, the early bird applicants were most likely to suffer a delay in current year financial aid for spring.

Second, the financial aid offices were not adequately informed by Federal Student Aid (FSA), the office tasked with administering federal student financial aid for the United States Department of Education. Financial aid administrators were told by FSA that only records with substantial changes to need-based federal aid would be impacted. Later, since the federal government would not disclose what fields were in conflict, the financial aid offices were left to work with the students and families to identify and resolve all the conflicting information. This caused uncertainty regarding how to proceed and led to fishing expeditions in aid offices until the aid administrators had a sufficient understanding of what they needed to search for in the files to identify the conflicting information.

\section{Research Question}

What did aid administrators perceive to be the impact of PPY on students and aid offices?

\section{Industry Acronyms}

DRT - Data Retrieval Tool

FAFSA - Free Application for Federal Student Aid FINAID-L - National list serve of financial aid administrators

FSA - Federal Student Aid

NASFAA - National Association of Financial Aid Administrators

PPY - Prior-Prior Year

PY - Prior Year

\section{Review of Research}

\section{Prior-Prior Year}

In 1997, the Advisory Committee on Student Financial Assistance published a briefing paper cautioning against using PPY income for federal financial aid application purposes. The paper argued that $63 \%$ of aid applicants would have their income over or underestimated and, among other things, PPY would cause a redistribution of federal aid from more financially deserving students to less financially deserving students (Advisory Committee on Student Financial Assistance, 1997).

In 1998, a study focusing on the feasibility of using PPY versus PY income found that PPY was $82 \%$ accurate in predicting current year versus $87 \%$ with PY (Kelchen, 2014; Kelchen \& Jones, 2015; National Association of Student Financial Aid Administrators (NASFAA), 2013). A later study published in 2012 found that $77 \%$ of students using PPY would have a 
Pell Grant within $\$ 500$ of their Pell Grant using PY data (Dynarski \& Wiederspan, 2012).

The NASFAA committed a great deal of time and research to ascertaining the pros and cons of the change to PPY(Coval, 2015). It also completed an administrative burden survey of members. The top recommendation from the survey was that PPY be implemented (National Association of Student Financial Aid Administrators (NASFAA), 2015). According to the publication, the three greatest benefits of PPY to students were as follows: 1) the ability to file the FAFSA earlier, 2) Easier and more accurate filing, and 3) the option to use the IRS Data Retrieval Tool (DRT) to avoid verification. [The DRT allows federal income tax form information to flow from the IRS to the Department of Education when authorized via the FAFSA.]

In their study, Kelchen and Jones found results similar to Dynarski and Wiederspan. They also found that students narrowly eligible for Pell Grants, as well as independent students who worked before college would be more likely to lose Pell Grants under PPY(Kelchen \& Jones, 2015). In their conclusion, Kelchen and Jones called for a multi-region or multi-state pilot to track these concerns, encouraging a sensitivity toward those who were likely the most negatively impacted (2015).

Additional concerns were raised, including the impact of having to make labor-intensive professional judgements (a manual assessment of what financial aid would have been under different conditions than those reported on the FAFSA) when the PPY income is significantly higher than the immediately PY income. Approximately 1.5\% of Pell recipients in 2011-2012 received professional judgements. An uptick in this by even a single percent would represent a considerable workload increase for financial aid administrators (Kelchen \& Jones, 2015). Researchers hoped that offering earlier filing would assist those students who under-file (those who miss state grant deadlines) as under-filers tend to be the most financially needy of students (Cannon \& Goldrick-Rab, 2016).

A piece written days after President Obama's Executive Order to move to PPY articulated what many feared: this one change could upend the historical uncertainty associated with college selection. In particular, Boekenstedt lists out the several possible unintended consequences including (1) allowing schools to be less need-blind in their admissions, which would hurt the very students this policy was intended to help, (2) more savvy students hedging their bets while price shopping longer, and (3) the elongation of the negotiation season where families leverage school A's financial aid offer against school B's financial aid offer (Boeckenstedt, 2015).

As PPY was enacted via an executive order, the typical rulemaking process involving the aid community did not occur. FSA chose not to offer prepopulated values in the online FAFSA to prevent re-asking for the same values requested in the previous year from reapplicants. In fact, anticipating families would provide different answers, FSA instead invested in creating a new series of edits to find differences. The primary tool for communicating to financial aid administrators that an application has a conflicting answer when compared to the previous year was the comment code 399 flag.

Students whose records were flagged with comment code 399 received a message stating, "Your Financial Aid Administrator may contact you to resolve any issues related to differences in the 2015 income information you reported on your 2016-2017 FAFSA and 2017-2018 FAFSA." Aid administrators were told "Resolution required. Institution must resolve the possible conflicting information" (Federal Student Aid (FSA), 2016b). However, FSA did not provide guidance on which fields were in conflict and the aid office was left to figure out the how to resolve the disparity.

In the fall of 2016, FSA relaxed some of the requirements associated with comment code 399. In particular, "an institution is not required to resolve the reported Comment Code 399 if...the student was, or will be, a graduate student for all of 2016-2017 and will continue to be a graduate student for all of 2017-2018; and [t]he student did not, and will not, receive Federal WorkStudy for either the 2016-2017 or 2017-2018 award years" (Baker, 2016).

During this study conducted in Spring 2017, the DRT was shut down at the beginning of March due to IRS "privacy concerns" (Douglas-Gabriel, 2017; Internal Revenue Service, 2017) and, according to reports, it would not be reinstated until the fall (Federal Student Aid (FSA), 2017); therefore, the most at-risk filing population, that which under-filed, would be that most likely hurt by the unavailability of the DRT. Moreover, according to an April 2017 NASFAA survey, 23\% of those polled indicated they already saw an increase in the number of comment code 399 records (National Association of Student Financial Aid Administrators, 2017). 


\section{The Protocol}

The method for this research was qualitative in nature to allow for a more open, exploratory discovery of the underlying financial aid administrators' perceptions of the implementation of Prior-Prior Year.

According to Creswell, a phenomenological study is an "exploration of this phenomenon with a group of individuals who have all experienced the phenomenon [...where] a heterogenous group is identified that may vary in size from 3 to 4 individuals to 10 to 15 ." He describes the research as "somewhere on a continuum between qualitative and quantitative" (Creswell, 2012). Creswell goes on to note that the researcher "brackets" himself out of the study, as opposed to an approach like action research where the researcher intervenes. He goes on to state that the research approach collects data from those who have experienced the phenomenon, the units of analysis can be gradient, and the end product is a discussion of the "essence" of the experience.

A phenomenological study method was chosen as it allowed exploration of the topic rather than predefining what should and should not be measured through a more positivistic approach. Instead this study allowed the interviewees to go into detail regarding how they got where they were, what they saw happen, what they believed to be relevant, and how they felt about the subject.

\section{Sample}

The sample size was based on phenomenological research recommendations from Polkinghorne to interview 5 to 25 people (Polkinghorne, 1989). In accordance with this guideline, five individuals were interviewed about their experience with implementing Prior-Prior Year (see Table 1 profiles). They were also asked about records marked with Institutional Student Information Record (ISIR) Comment Code 399.

According to NASFAA, $21 \%$ of aid officers are male (National Association of Student Financial Aid Administrators, 2016). As such, the desired sample was 4 females to reflect the distribution. Unfortunately, the actual response rate among females was very low, and the ratio of female to male participants ended up being only 2 to 3 .

The researcher did not choose to include any impacted financial aid applicants in the study because only a student who worked in her institution's financial aid office or had a close relationship with an aid officer would likely know or be able to identify if he or she was impacted by this regulation. The assignment of code 399 by the Department of Education was not readily obvious to the student.

\section{Study Design}

The researcher has worked in Financial Aid and was a great proponent of PPY. PPY was discussed frequently during the researcher's formative years in financial aid as a workstudy student in the early 1990s. As such, it was necessary for the researcher to acknowledge this bias in preparation for the study. In addition, the researcher owns a financial aid software consulting firm, and was careful to only accept participants who did not use her firm and were not currently working directly with her. The researcher also acknowledged that reporting on implementation shortcomings by Federal Student Aid may create tension between her firm and FSA.

\section{Procedure}

1. The researcher attempted to post a request for interviews (stating the expectation of at least one interview and maybe a second) on FINAID-L. According to FinAid.org, FINAID-L is a "discussion list for issues facing financial aid offices" focusing on topics such as "changes in federal aid regulations" (FinAid.org). The request to post was denied because the researcher's assertion that this research was for academic purposes was belied by his affiliation with a for-profit financial aid software consulting firm.

2. The researcher successfully posted requests for interviews on LinkedIn and Twitter. Requests for interviews included:

a. Informed Consent document.

b. Demographic Information supplemental document.

3. The interviews were conducted over a two-month period after obtaining both forms.

4. Interviews were recorded on Just Press Record (an iPhone app) and join.me.

5. No money or benefits were offered to participants.

6. The interview questions that drove the primary interview were used in all interviews.

7. Before starting each interview, the participant was reminded of his or her right to stop the interview 
at any time and to decline to answer any question.

8. Each interview lasted between 46 and 69 minutes with an average of 58 minutes.

9. All interviews were transcribed by www.rev.com.

10. Interviews were then read and listened to multiple times to identify emergent themes across all participants.

\section{Analysis}

Moustakas' method as described in Creswell's Qualitative Inquiry and Research Design was employed (2012). The collected interview data were read and listened to multiple times. General concepts were gathered and then captured in a spreadsheet. Significant statements supporting the concepts were identified. Meanings were then determined based on the significant statements. The meanings were then grouped into themes common to the participants.

Table 1: Participant Profiles

\begin{tabular}{|l|l|}
\hline Participant & \multicolumn{1}{|c|}{ Key Demographics } \\
\hline 1 & $\begin{array}{l}\text { Director of Financial Aid at a private, non-profit college within doctoral-level univer- } \\
\text { sity } \\
\text { Large institution (more than 10,000 students) } \\
\text { Worked in financial aid for } 33 \text { years } \\
\text { Undergraduate Degree: Music }\end{array}$ \\
\hline 2 & $\begin{array}{l}\text { Associate Director of Financial Aid at a private, nonprofit graduate and undergradu- } \\
\text { ate university } \\
\text { Medium institution (between } 2,500 \text { and } 10,000 \text { students) } \\
\text { Worked in financial aid for } 17 \text { years in for-profit, state, and private non-profit schools } \\
\text { Undergraduate Degree: Sociology }\end{array}$ \\
\hline 3 & $\begin{array}{l}\text { Associate Director of Financial Aid at a private, non-profit graduate and undergradu- } \\
\text { ate university } \\
\text { Small institution (less than 2,500 students) } \\
\text { Worked in financial aid for } 16 \text { years in a community college and private non-profit } \\
\text { schools } \\
\text { Undergraduate Degree: Communications }\end{array}$ \\
$\begin{array}{l}\text { Director of Financial Aid at a private, non-profit undergraduate university } \\
\text { Small institution (less than } 2,500 \text { students) } \\
\text { Worked in financial aid for } 33 \text { years } \\
\text { Undergraduate Degree: Film }\end{array}$ \\
\hline 4 & $\begin{array}{l}\text { Executive Director of Financial Aid at a public community college } \\
\text { Large institution (more than } 10,000 \text { students) } \\
\text { Worked in financial aid for } 17 \text { years } \\
\text { Undergraduate Degree: Biology }\end{array}$ \\
\hline 5 &
\end{tabular}

\section{Findings}

The participant with the earliest recollection set the tone with his observations about the way that PPY was perceived in the profession:

A lot of people were complaining that [PPY] would drastically increase the number of professional judgment calls we'd be asked to make because you were widening that window of time between the earning of the income that was being reported and the beginning of the enrollment that using financial aid determined by that income. You already had things, adjustments to possibly make from a prior year. If you go back two years, you're talking about even more adjustments, so that was always the objection. I think for a long time, those objections were drowning out the argument about the potential advantages of it... I thought it was something worth looking into. I don't remember having a really strong opinion to it, about it. I was not on board with the people who were completely opposed to it because of the fear that it would increase the number of professional judgment adjustment requests because that's not a very student-centered way to look at this.

Participant \#1 


\section{Theme 1: In some ways, Prior-Prior Year had a few pleasant surprises...}

My initial thoughts, because I was still at a public [university] at the time, my initial thoughts were that it was not going to be a good idea, simply because I was very concerned about the number of income adjustments that we would have to make because of people's life changes. I mean, we have enough from one year to another, but then going back two years, I was just very concerned about people getting married, people getting divorced, people losing their jobs. So, I was just concerned about the number of professional judgments that were going to need to be done.... I think getting the information out to our high school seniors sooner is definitely a good thing.

Participant \#2

I first heard about prior-prior in the early '90s. Probably the mid-1990s. It was always one of these things that was just sort of getting kicked around and nobody really took seriously...I'm not sure that anybody really, really thought that it was going to come about. Certainly not in my orbit here in the Philadelphia area. I know that none of us who had talked about it ever could imagine that it would actually work. I think that we were all pretty cynical about it. In fact, I know a lot of us were cynical about it right up to the moment where we were forced in it. Here's the funny thing, a lot of the high-end colleges were vehement against it. No-

body wanted to change. Nobody wanted to do it. Everybody saw that there's a logic to this, that if you use data that's two years old, it's going to be less than an accurate measure of somebody's finances now than if you use information that's one year old. The argument against it certainly had logic to it, but I have to say, sitting here at [my school] where we do.... We have early decision, which is all admissions realm. Admissions decides applicants between mid-November, mid-December, and the financial aid decisions go out with those decisions in mid-December, so you were always used to having people fill out the Profile, having them guess what next year's income was going to be, and then actually wait until they file their taxes and go back and re-do it. I did at least know, when prior-prior year was coming, I was like, "Please. We will now actually have the accurate information. We don't have to chase these people afterwards. We're going to get it up front on the Profile." I still anticipated that there would be a lot more appeals because again information two years old is theoretically going to be less an accurate picture than information one year old. I haven't seen that happen. I'm not seeing any more appeals coming through this office.... [B] ut having anticipated that prior-prior year was going to be something of a disaster, I have to say, it has been very, very smooth.

Participant \#4

We're right at 13,000 ISIRs. Prior to the prior-prior year ... Normally, the application becomes available January one, by this time of year, we probably would only have eight or nine thousand ISIRs. Typically, our students wait very late to apply. They're a much more adult population, average age 29. We used to get the majority of our ISRs in April, May and June. Actually, it would have been probably more like May, June and even into July. The majority of our 30-to40,000 ISIRs come in in those three months. The prior-prior year, coming up in October, has really helped us. We're at almost double. In the last couple of weeks, we doubled the normal amount of ISIRs that we normally would have at this point in time. So that's a good sign, I think, going into summertime, that if we can keep up that trend of staying about twice as many ISIRs received as in previous years, by the time we get to April, May, June, July, August, our busiest months of the year, we may not be as busy because we've gotten so many kids filling out the FAFSA so much earlier. I think prior-prior year is helping students fill out the FAFSA earlier. Because a lot of our students, especially our adult students, even though we say you could go fill out the FAFSA and then just use estimated data, and then fill it back out, I think the majority of our students waited until after they filed their taxes before they actually did the FAFSA application.

Participant \#5

The...thing that I think is positive about the prior-prior year is, at our institution, we generally would award our returning students in June,... that's around the time that we would start verifying them, and we would award them whether they'd been verified or not, so they would get [an] estimated letter. Because the FAFSA's available so much earlier this year, we're actually going to require a student to be verified, if they're selected, prior to getting their award in June. We're doing that in order to, one, ensure that we're awarding them accurate information, because we don't want a student getting a Pell grant in June, being selected for verification, finally getting us their documents in October, and losing their whole Pell grant, which is what could potentially happen, and what has happened in the past. Now, we're say- 
ing, "Hey, listen, you were selected for verification. You filled your FAFSA out in January. We've been asking you for documents since then. We will wait to do your financial aid award until you get us your verification documents." We're hoping that that will do two things. One, we'll provide students with accurate awards upfront, because they're already verified. Two, it will prevent us from chasing students down in October and November and canceling aid because they haven't gotten us the documents. As part of that, though, we're not reducing or eliminating aid.

Participant \#3

\section{Theme 2: ...but Comment Code 399 was a missed opportunity for FSA to collaborate}

When discussing the challenges faced by students whose spring aid was delayed due to getting a comment code 399, Participant \# 1 stated, "[A] student's landlord doesn't care about 399s that have to be resolved."

They... assured us that we're only going to have to resolve these issues if it really makes a significant difference, that the department would be checking to see how much of a difference this really makes to a student and would be focusing most$l y$, if not entirely, on students whose Pell grants changed. Here we are now seeing 399s for students, graduate students whose package consists of an unsubsidized loan and a plus loan, where it doesn't matter if their family contribution is zero or a million. They qualify for the exact same thing... Probably just back to the theme of "It's always better to plan ahead and get everybody in the loop." These are not new lessons. Our friends at the Department should have done a much better job in having a plan in place. They knew this was likely to be coming. The conversations about how some of the things were going to be rolled out, especially the 399 s, could have taken place much earlier... They've been through things like this before. They should have known.

Participant \#1

[A comment code 399] does take a lot of time to resolve, because you're looking at the two years. I actually print the student and the parent student financial page from PowerFAIDS for both years so that I can look at them side by side, see exactly what is wrong. I highlight it. I put comments in. I put a cross-year edit validation on 16-17 so that we don't disburse any more aid. I send the letter out. So, it is time consuming to resolve. It really is. And this is only the people with the 399 code. We also have people that we aren't even looking at that don't match, and some of them could be potential issues that come up because they may have Pell in one year, but whatever they did on their FAFSA in the other year is not making them Pell-eligible. So, they aren't even coming up with the 399 code.... We did have to pull back spring aid for some of them, because they had not been resolved yet. I think all of those have pretty much turned in their paperwork at this point, and if they haven't, they're not going to be able to register [for fall semester], so even though I sent letters home and put the documents out there, and we emailed them about pulling back the aid, if they haven't turned it in yet, probably the first time I'm going to hear from them is when they go to register and find out that they can't. So yes, we did have some that we had to pull back aid for. The other ones, for 16-17, we have not pulled aid back yet, but have prevented disbursement of spring aid. Some of them that I'm getting right now, obviously, their spring aid has already paid, so I'm going to have to, over the next several months, I'm probably going to have to monitor them a little bit more closely, because I don't want them to leave for the year thinking that everything is okay and that they can keep their 16-17 aid, because eventually, we're going to get to a point where were going to have to pull that back too, for the whole year, if they don't resolve it.... Sometimes it feels like there's a disconnect between the regulation and reality. Just because I don't think [those at FSA] fully understand the difficulty in dealing face-to-face with families.... I think there's a disconnect sometimes. They don't fully understand how much time it takes and what the realities of people's real lives are.

Participant \#2

I'm sending a personal email [to each student with comment code 399] and I'm trying to explain in this email, "This is what's happening. This is what you reported last year. This is what you reported this year." I'm sending it to the student and then I'm forwarding it to their parent, and then the parent's calling me, so I take that, as far as the experience goes, that there's a lot of talking to multiple people.... I'm dealing with one specific student. She's one who we did an update for. She was selected for verification afterwards in 16-17, the EFC did not change, which was surprising. Then I had to say, "Okay, now I need this other information," and we're having a hard time getting the information. Her mom doesn't want to do the retrieval, when it was back up, but her mom swears she sent us tax returns, when she sent us tax forms, so it is equally frustrating for the student. She's do- 
ing everything that she can, and the mom's trying to do everything she can, but you know, she just has very specific ways she wants to do things.... I'm into March now, and the student still has a balance because her aid is not disbursed, so I'm taking her hold off, making sure she can still do what she's doing, because she's trying to work as hard as she can to get everything that we need. The issue was so small... and I remember being so annoyed, because it was so small. It didn't even change her EFC.

Participant \#3

Fortunately, the 399 thing goes away next year. It was a one-year anomaly. I'm hoping that when the feds do audit schools that they're able to be a little sympathetic about that. It's hard to tell. Sometimes that depends on the auditors. I think that because it's something different, and it has an impact not just for whether somebody can get aid for the upcoming 17-18 year, but it could impact their 16-17 financial aid, which let's face it, ... that has all been paid out by now, including any refunds that somebody might be eligible for. A lot of schools are sweating that, that they have to actually [change a student's aid] or pull money back from a year that is almost over or at least was almost half over at the time that all of this kicked in.

\section{Participant \#4}

My biggest concern was, if we don't load ISRs until January or February, but that's a 399, and we made a disbursement on a student file and, since then, that's out of compliance. It was rocky because I think in October and November, the feds really hadn't given the best guidance on that. We know that there were several instances where they were flagging kids for 399 that really shouldn't have been. I think there was a lot of nuance in students that ... What we found is, there was a lot of students that, they used the DRT this year and last year, all the data off the DRT was the same, their household size is the same, and you wonder why they got a 399 code. It's because some non-verifiable field is different. Some taxed income field that's not necessarily verifiable. Obviously, that is part of the normal V-group verification. I think that opened up some eyes and caused some initial frustration with the process. I don't even think the feds knew all about what students were going to be selected and why. Insomuch as they didn't realize that it would be confusing for colleges that, if they were being selected for 399 because a non-verifiable field was different, that was something that was out of the norm for schools.

Participant \#5

\section{Theme 3: Federal Regulation burden is worrisome}

There is too much expected of financial aid administrators when it comes to regulation. I have the expectation of following federal regulation when it comes to awarding and things like that. When it comes to 399, we get that it is only one year, we get it, but the amount of resources it's taking [is high]. We are fortunate, we're fairly small. But I have a colleague who works at a state institution and their 399s are out of control. And it is taking them so long to get through [the 399 codes] that the students didn't get their aid disbursed. Students weren't getting their refunds.... [T] hey forget that most aid offices are understaffed and overworked.... [A]nd they expect us to be...tax experts. I'm not an IRS expert.... Do you think [families] want me to tell them they have to amend their taxes? And then they get me a letter from their accountant saying, "Oh, no, it's fine." ... [T] hey have a very high expectation for what we do and we want to be good stewards of federal funding....[I]t's a lot and it's decided without a lot of input from us... I feel like the government's always going to be the government, and they're going to make the decisions without really knowing how burdensome and inefficient they are.

Participant \#3

$[E]$ specially with all of the gainful employment regulations, I think that [proprietary schools'] hands have really been tied in a lot of ways that was necessary in some respects because of the bad actors in that group. But it definitely hurts the good ones, I think, to have some of those regulations in place are just very burdensome.

Participant \#2

$[M] y$ feeling is that prior-prior year did not really come about so much as an efficiency. What I've been seeing over the years is more and more suspicion on the part of the federal government. I think really starting with the big witch hunt of 2008. They weren't trusting colleges. They weren't trusting financial aid people, and I think a lot of that distrust has finally moved to parents. I saw that in parents because I see it in the fact that we used to do verification with copies of tax returns, but no, now it has to be an IRS tax transcript. I think the IRS data tool was, again, something to try and make sure that people are not cheating, and that prior-prior year is [to] encourage that much more use for the IRS data tool. I'm not really happy with the attitude that has brought these regulations and changes around. I mean, you think it's in other areas, too: the unusual enrollment regu- 
lations and such; that kind of thing. I do think that prior-prior year, from the federal government's point of view, is trying to catch offenders.... I just wish there was a more honorable motive for [PPY's] existence.

Participant \#4

[Gainful employment regulation] was just extremely overburdensome for really no reason. It's a give and take. You have to understand that [FSA has] a job to do. We have a job to do. We may not like how it's implemented, all the time. But I do think that the majority of people there are trying to implement it the most equitable way possible. It goes back to, I think, fundamentally, we no longer have the college university system we had in the 60s when the Higher Education Act was written. I think too many laws are passed viewing college as 18-to-24-year-olds who go to college, fall and spring, for 15 credit hours, take summers off to get a job and help pay for tuition and fees, and that's the typical college student. When that is the atypical college student. There was a good line in the congressional hearing yesterday, I forget who did it, who said it, but when they talked about the non-standard student, or the non-traditional student. She said, "Realistically, the non-traditional student of today is the typical student." That 18-to-24-year-old college kid who goes fall, spring. That's the non-standard student. The standard student, today, is the mid-20s, community college, state college, non-typical fall, spring student. They may take a term off, they may take mini-module semesters, they may take online classes. That's the typical student today. We really need to stop legislating for that traditional college model that hasn't existed, and may have never existed, versus how colleges actually work today. To me, the regulations are written that fit the...big state universities, the big private universities, and don't really work well, don't really help, community college students.

Participant \#5

I think [PPY] was an example of something that the department didn't deliver what they had promised. I've, on two occasions been on negotiated rule making committees, so I have some insight as to how these regulations are written. They are genuinely written with real input from real experts. It's not just top down stuff from the department, but things like 399 is, that's top regulatory. That's just a procedural thing that the department comes up with. There's always... We have to follow laws. We have to follow regulations, but then we just get things handed down from the department that are not really regulations.
They're just procedural things. Those are where there's the most gray area because it's created without input. Sometimes the department doesn't think it all the way through, the way they should. This whole 399 thing was a great example of that. I think there have been some times recently when there's been some tension between the department and the aid community. There was a hearing about a year ago where Justin Draeger, President of NASFAA, spoke before Congress and really kind of hammered the department on a few things that had been rolled out in a very sloppy way, especially gainful employment regulations. Sometimes the department then goes and pouts. We see fewer department event sessions at the following NAFSAA conference because they're mad at us, things like that. Yeah. Sometimes it becomes a little bit of a territorial thing or a love hate relationship. I have a lot of friends at the Department of Education. We've worked together really well. I ask them for guidance and they ask me for guidance, but the Department of Education is a huge entity. There are some things that the aid community sometimes has very limited input in...

Participant \#1

Theme 4: The term "college affordability" seems to be broken

When asked the meaning of college affordability, financial aid administrators sensed the goal of the question but struggled both with defining the term and with speculating whether schools were meeting this goal.

I guess college affordability to me is... another kind of easy but vague term. I mean, I'm not sure exactly.... I think people can throw out the term college affordability and mean a number of different things. I think that, for families, college affordability could be just simply, "Okay. After I get this financial aid, and I see what the bottom line is, literally, can we afford this?" Then, are you also going to measure that against the value of the education and what your child is going to come out of college capable of doing afterwards? Can that be factored in? It should be. I have an 18-year-old daughter just now, today, getting accepted to colleges, and she's looking at one college, and she's looking at another, and she's seeing how much money she can get. She's really trying to weigh what her career options are going to be when she gets out. We're talking a liberal arts education. We're not shoving career down her throat, but she realizes that she does not want to come out of college and not know what to do. She wants a college that can support her in the post-graduate process, and that's part of what she factors in, when she's factoring 
what's it going to cost to go. Yeah. I mean, it can become a buzz phrase so easily.

Participant \#4

I think that college affordability, as a term, sounds good. I think that while institutions claim they want to strive for affordability, I believe that most of the time they're not really on point, especially private institutions, because there is a difference between giving somebody enough financial aid to pay for their tuition and actually having college be affordable when they get here.

Participant \#3

It used to mean a financial aid. To me, now, it really has to mean costs upfront because I don't think the industry has done nearly as much as it should over the years at containing the cost to students and families. It's not just a financial aid issue anymore. It's the sticker price, to begin with. It's something that in the past $X$ number of years, the industry has not done a very good job at.... It's not just colleges. As most students in American Higher Ed attend public colleges, states have not done their part either. Much of the time [politicians] will sit back and grandstanding about college costs, while at the same time voting to cut funding. There's a lot of political hypocrisy going on with that.... College affordability becomes a public policy issue as well as decisions that are made on campuses. Obviously, can say private colleges, like the one I'm at now, can't use that excuse. Looking at this globally, what is it, something like [70 or 80 percent] of students in higher education [are in the] public sector.

Participant \#1

The following observation came from one of the participants, who worked at private for-profit, state, and private not-for-profit schools, discussing the various perspectives of college affordability in the contexts of those different environments:

Some of our programs at the proprietary school were very, very affordable. Students, in some cases, if they had lower EFCs would not even have needed to take out an alternative loan to be completely covered. Other programs were very expensive. I mean, when I left there in 2007, I think the higher cost program for an associate's degree was their computer science programs and their culinary programs, and they were getting close to about $\$ 35,000$ for a two-year program. So those students did need alternative loans, and I kind of think, in the proprietary world, some of that, it just is what it is. I mean, I feel that I worked at a good proprietary school. There's a lot of not so good ones out there, but I think I worked at a good proprietary school. It had a good reputation, it had good programs that led to gainful employment for students. They had a very good career development office there that definitely helps students a lot to get employed in their field, not just get a job.... At the public, the reason that I left there really was because their affordability, I felt, as a public school was becoming out of range, and it wasn't even so much the tuition. It was all of the new housing that was being built. It got to the point where the housing and meals were more expensive than the tuition, and I had very great concerns about what that was saying to our students about what was really important. Was it more important to get an education and live in a cinder block dorm room, like was common in the ' $60 \mathrm{~s}$, '70s, and ' $80 \mathrm{~s}$, or is it more important to live in a suite-style, almost bordering on a hotel, that has all the amenities and everything you could possibly want, and knowing full well that a lot of those newer dorms are much, much better housing than where the student is living at home. I can certainly understand why they would want to live there, but is it really affordable? And it's just a different mindset, I guess, of the modern student that wants to be comfortable while they learn. So that's really why I left the public school. And yeah, here at a private, there is some concern about affordability, but at least we have flexibility with students in that they do have merit aid, they do have an appeal process, where they can ask for more money, and we will help them do whatever is possible for them, offer suggestions, tell them where to look for scholarships, tell them to go talk to their guidance counselors, as well as offer as many things as we can. Unfortunately, no matter what type of school it is, there's always going to be some students that absolutely just cannot afford it, no matter what. And whether that, unfortunately, is due to poor credit history on their parents' part or unwillingness on their parents' part to help them, there's always going to be some students like that. Is there concern about affordability? Sure, but everything is going up in price as well. You go to buy a new car, and it's expensive too. So I think that people need to think about that as they're making their college selections, and not just be looking at, "Okay, well school A offered me X amount of dollars, and school B offered me Y amount of dollars. Can you match school A?" Well, maybe, but maybe we don't have to, because even though we're offering you less, our overall cost is less, so I think sometimes, parents just don't understand that either. 
Participant \#2

Another participant expanded on the need to have an earnest conversation about students and families making sustainable decisions within the context of the resources required from parents or future generations to afford an expensive education now:

It's funny, in the committee hearing that they had on Capitol Hill the other day, they kept bringing up the Bennett [Hypothesis] which is the idea of the more financial aid they provide, the higher tuition fees are. If you raise college financial aid maximums, you immediately go into, well, then it means colleges are just going to raise their costs. I think that does a disservice to college affordability. I think college is extremely affordable if you make the right, informed decisions.... When the government, when the feds, when the Department of Education, when news media portrays college affordability, they paint it through the lens of the traditional universities. The Notre Dames, the Harvards, the Yales, the Dukes, or Vanderbilts. Or the big state universities, the flagship state universities, University of Michigan, Texas, Florida. Those are very expensive schools. Even some of the Texas, Ohio State, even though they're state schools, they're not that expensive. But the reality is sixty to sixty-five percent of all college students in America are at community and state colleges, which are the more affordable options. I think if you can afford to go to NYU at $\$ 80,000$ a year, great.

That's affordable for you. If you can't, then there are extremely affordable options. I think the argument is too nuanced for a Twitter feed. 256 characters. It's too complex a thing to really just boil down to a sentence or two. Is college affordable? Yes. Can it become extremely unaffordable if you make the wrong decisions? Absolutely. I think that's the argument that needs to happen in the discussion about college affordability. How do we make sure that each family is given all the information they need where that it's not information overload, but they can compare apples to apples and make some smart decisions? The other aspect, too, is even though you are a bright, really good student, and you can get in to the University of Florida, or Vanderbilt, maybe it's better for you to go to community college for two years because it cuts your cost in half. Yeah, you're a first gen student and your parents don't make a lot of money. Why burden yourself with $\$ 50,000$ in loan debt? If you go to [a community] college and get your bachelor's degree, and then go off in the work force, and you make more money, your kids can go to Vanderbilt because you'll have the financial support for it. That's where I come from my dad. My father didn't graduate high school. He always would tell me, "Look, I'm working two jobs as a truck driver and volunteering as a fireman so that I can afford to make sure that you have a better life. You make sure that you sacrifice and do things to make sure that your kid has a better life." We always think about ourselves, a lot, in a society, and not think generationally. We have all these kids that come to community college and they're going to be a nurse but they can't pass, or they can't even get out of, remedial math. You have to be willing to have a hard conversation with a student and say, "Look, you're probably not going to become a nurse, but I have all these other programs that you can get, affordably, that then, you could get a really good paying job and be able to support a family, so that maybe your kid has a better chance of becoming a nurse or a doctor, or something like that." I think that's where we talk about college affordability we always want to go from zero to 1,000 in the first jump and that's not always the case. Sometimes you have to take those baby steps. Work down the road. Get the associate's degree now, come back to get a baccalaureate later.

Participant \#5

Building on the theme of the college affordability discussion being skewed toward a small sector of higher education, Participant \#3 stated:

[Y]ou know, whenever a reporter or media wants to talk about financial aid, they're always talking to the same institutions, right? We're talking to the Ivies and we're talking to these institutions that we expect financial aid to be change makers or change agents, but they're so, they're just the smallest little piece of what really financial aid is, and what the financial aid office is or being a student on financial aid is all about. I'd like to see a broader, larger conversation. There are too many colleges, people in state schools, people at private schools that maybe really struggle to get their enrollment, because...I don't think there's a really good sense of what financial aid is out in the world. Affordability, access, aid, things like that.

\section{Theme 5: Financial Aid Administrators did not plan to become FAAs but none- theless have a shared passion and, often, history}

If you went into the NASFAA conference with five thousand financial aid professionals and said, "Raise your hand who went to college with the goal of working in financial aid," you'd basically have no one would raise their hand. But if you [instead] asked how many were first-gens or were work study stu- 
dents in college and fell in love with the idea of helping people, in a way that, "you're not going to get paid well and you're not going to get a lot of recognition for it, in fact you're going to get beat up more often than not," thousands of hands would go up.... I think when I went in grad school and learned how much of a [financial] burden it can be, especially in first gen families, it became a passion of mine. I volunteer every year and I go and talk at the NACAC fair to thousands of students. I talk about my experience. I tell them what mistakes I made, the reason why I'm here today volunteering my time. I'm not here for my college. I don't care if you go to my school or not. I just want you to make the right choice, financially, for you and your family.

Participant \#5

Financial aid administrators do not appear to have started out with the intention of becoming such. To quote Participant \#4: "I don't know anybody who plans to get into financial aid." In the words of another participant:

I can't say I ever [lost my passion for working in financial aid]. I really can't. It wasn't my life goal as a young man or anything, but I ... Actually, a colleague of mine... who was also involved in the training for the NASFAA leadership conference, had a line in a group panel we did together that I really liked. He said, "You bloom where you're planted." I, like everyone else in this business, I did not grow up wanting to be a financial aid administrator, but I became one and I think in ways I got pretty good at it. I got to learn a lot about it and it became like, "Okay, this is what I do." I have other interests in life, but when it comes to the need for having to get up every day and go earn a paycheck, that part of me is a financial aid administrator... I can't really say I ever lost my passion for it, which obviously, it has its frustrations, but so does everything. I consider myself very fortunate that I have not had a time where I've said, "Gee, I wish I wasn't doing this anymore."

\section{Participant \#1}

Participant \#2 said, "[W]ho starts out graduating from college thinking that this is what they want to do with life, and they want to be a financial aid officer?" Statements like these notwithstanding, the financial aid administrators who participated shared a common passion for their work.

I've been [working in financial aid] for 16 years, and
I've had my fair share of feeling burnt out, in lots of different ways, where I'm just tired of telling people, "I'm sorry I can't offer you more financial aid." When you get to that point of the year where everybody's received their aid packages and they're calling you and they're saying, "I need more," or when some new regulation happens and you're trying to scramble and figure out, "Will [the] software system allow for it? Will [I] have to do it all manually?" I think that if I wasn't passionate about it, if I didn't feel like it was something that I should be doing, that I probably would have left a while ago, because there's a lot of hard times. You're kind of exhausted. You're tired of telling people no, and you're tired of reports and taking money away because you found out somebody didn't do something right. I would say that anybody who sticks with it for this long has to be passionate about it, right? Has to be.

Participant \#3

I don't know that I've ever lost my passion for it because I've always seen it. I've figured it out. It's one of these things that I just sort of took to. No one in my family ever thought that I would last at a desk job for more than a year. When I did make it through my first year of financial aid, my mother confessed to me that she was surprised that I lasted a year. She expected me to quit within the first couple of weeks, ...I was able to spot it. I was able to see what financial aid does for people, what a difference it does make. It doesn't show on their academic transcript. It's not going to show up in their resume, but you're getting students through college and hopefully, they're getting through the college that they want to. Hopefully, they're getting through with some level of debt that they can manage, which is harder and harder every year.

Participant \#4

All but one participant received financial aid. The one who did not receive financial aid reported this experience:

My choices were kind of limited because I remember my high school guidance counselor saying, "Well, you're a middle-class kid, so you're not going to qualify for financial aid, so you'd better go to a state college." Whether or not it was true that I wouldn't qualify, we never really found out because this was back in the 70s and guidance counselors might not have really been up on these things very well.

Participant \#1 
Theme 6: The work of a financial aid administrator is meaningful but difficult and overlooked

I would say that it is a really, really delicate balance of wading through bureaucracy, whether it's federal, state or institutional. But also, being a good counselor, people person, listener, creative, outside-thebox thinker, because we are so rigid. We have really specific federal regulations that we have to follow in order to maintain our compliance and keep our aid. However, we're also given professional judgment from the federal government to make adjustments to situations that may need them. I think finding a person that can do both of them, that can think both ways, being really rigid, which is how I always was, and the professional judgment part was the piece that I really had to learn and grow into and realize that one half of me has to be black and white, but then the other half of me can be a little gray. I think that people forget the part where we do listen to people and we do want to know what experience in their family situations are. We're not just here to process forms and deny people their dreams. I think it's hard.

Participant \#3 ly easy job, go do something else for a living."

Well, I think on a daily basis, everybody feels frustrations, and it certainly can get to you at a point when it's really busy, like August and January are extremely busy times, because it's the beginning of the semester. And I think anytime that anyone loses that passion, it's probably due to being overwhelmed and being frustrated with the amount of work that you have to do, and not enough hours in the day to get it done. So, when that happens to me, I just try to go home, not think about it, and refocus again the following day. Every day is a new day, and every day is an opportunity to get something done that you weren't able to do the day before. So I think you just have to keep that in mind, that while you have a frustrating day, and maybe a parent was yelling at you on the phone, or a student was snotty to you in person, that they aren't all like that, and there's a whole lot more out there that are grateful for your help. So, you just have to kick it to the side and move on. It's another day.

Participant \#2

There are certain things that are universal. If you want to be good at this job, you don't leave any stone unturned. You don't necessarily handle a student a particular way because it's the easier way. You still want to handle students in what is going to be the best way. You're always trying to do what is best for a student afford college that cant you, through your own efforts and the resources that are provided by your institution and by the various government agencies... if you can actually make that work, then you've actually done something that is going to influence a student's life for the rest of their life, hopefully for the better. That's really where the gut satisfaction in this business is.

Participant \#4

I would say [my job is] very meaningful. I mean, I personally have a passion for working with lower income students and first-generation students. I think it's extremely important for those students to go to school, because without that, they're just going to be perpetuating a cycle in their families that's never going to be broken if they don't get some education and get some ability to have an earning power that will drag their families and themselves out of poverty.

Participant \#2

Discussing the difficulties that come along with working in financial aid, Participant 1 said, "Yeah, it's going to take some more work. If you want a real- without breaching legality. We're always, always trying to find, each year, how to do the next year better than the year before. Can we get the financial aid to a student quicker than they've gotten it before? Can we make sure that they get all the aid that they're entitled to right off the front so that their bills are accurate, or is it going to be more aid coming in later that we don't know about, we don't have any control over? None of this is unique. Everyone in financial aid has to juggle this around.

Participant \#4

How I would describe financial aid as a profession is, people that deeply care about others and realize that it's something that is exceptionally complex. It takes years of understanding to really know how to do it. It's the ability of taking that complexity and trying your best to explain it to a layperson, to a first gen, or someone who's had three kids in colleges but different from your school. I think that's the way to explain it. It's not something you ever really go to college to do. It's something you find. It's almost like a calling, I would say because I don't know too many people 
that would want to do what we do, every day. We apply financial aid to thousands of students and you very rarely get the kids that are, "I've got the perfect amount of financial aid and I'm just stopping by to say thank you." Although you do get that, more often than not you get that $10 \%$ of the kids who are extremely unhappy. That didn't get enough money, or made some mistakes and lost eligibility, or just want to complain. You have to be able to deal with that, understanding that you're helping the greater good, and block out those troubled parts.

Participant \#5

Financial aid, we are often seen as the dream killers, and we're often the ones that pretty much have to give bad news, and it's not often we get the phone call of thanks from somebody, whether they decided to come or they didn't, but those times you do see students who make it through because of the help that you've given them. Those are the times that are worth it, and make you think, "Okay, well, maybe last year was more than just being a paper pusher for the government," which sometimes that's what we feel like we're doing.

$$
\text { Participant \#3 }
$$

When faced with the difficulties, financial aid administrators reach out to peers to support and teach them.

Having other friends in financial aid, I say it helps, because, you know, even if you're not talking about specific people, and you're just talking about things to vent to somebody who gets it... Like, I love my wife, but I'm not going to go home and complain about the 399, because she'll just look at me with a glazed look in her eyes. She'll try to understand, but you know, having friends and colleagues that work in financial aid really helps sometimes, too.

Participant \#3

Another thing I spend time trying to do is help NASFAA reaching out to train the people who will be doing this in the future because my future's not going to be forever. Thirty-three years means I'm, at the very least, on the back nine now. Weve got to make sure that this business keeps moving, so that the students and families who are going to keep needing it, the help more and more will continue to have people to turn to. When I see people younger than myself who have been in financial aid working on doctoral degrees, that's very encouraging.
They also help each other move on.

I don't hold onto every sad story that I get.... That's something that I had to kind of teach some of my staff members, too, because if you hold on to every sad story, you won't make it through the day. You're just slogging through feeling really bad about these people who you want to feel bad about, but you have to move on to the next, and not carry it over with you. They talk about psychologists and how psychologists have to have their own psychologist so that they can kind of get stuff off their chest after listening to everybody else's problems all day. I feel like that sometimes, you know, during certain times of the year where you're getting phone call after phone call and email after email, and you're done at the end of the day, you know, and you just wish that you had somebody anonymously that you could talk to that you could just be like, "Meh, here's everything," so that you kind of can move on and be fresh for the next day, when it happens again.

Participant \#3

Here are some participant comments regarding the complexity and the lack of visibility to students or other areas on campus:

I think we're in an odd kind of position at an institution, that we need to have a complete understanding of the entire institution, and I don't think a lot of people are aware of that. You know, because like faculty, faculty just deals with their little piece of the world, but as far as what we do, we have to make sure that our public safety or police officers are handling the Campus Crime and Security Act the way they're supposed to. We have to make sure that our bookstore is publishing book costs. We have to make sure that our faculty is taking attendance if it's an attendance-based school. We have to make sure that our registrar is properly entering information as far as withdrawals so we can do the calculations correctly. And I think that it's a very unusual job at an institution, in that we do have to have such a deep level knowledge of what goes on. I mean, you can't come into a school as a director and just step in and say, "Yep. I understand everything I need to do here," because if you don't know the pieces and how they relate, and where to go to get the information, you're going to have a difficult time. And I also think that a lot of the other campus offices aren't always aware of all of the regulations that are coming at us from all the different directions and how we deal with them.

Participant \#2 
It's meaningful for me because I never lost sight of what this job actually does, which is it does help students and their families pay to go to college. Yeah. There's not a student out there who's going to recognize that. There isn't a parent who won't recognize it beyond a fleeting moment, and that's okay because that's how it ought to be. When a student graduates, if they have good feelings about any particular areas of their college, it probably should be that special teacher and not some office administrator who managed to get the paperwork right so that the bills got paid. That's okay, but sitting where we are, we can see that function happen. We know that what we're doing is helping the student get through.

Participant \#4

I think that what stands out for me is kind of, is actually kind of something that isn't, doesn't stand out for many other people, is that aid administrators are really overlooked. I get that we have a negotiating role in aid and we have NASFAA, but we have an expertise in so many areas. We have expertise in regulations, we have expertise in compliance, we have expertise in many of us meeting and talking with people for, you know, under really difficult circumstances, talking about really personal things.

\section{Participant \#3}

After sharing a story about working with a fa-

ther to scramble to address some bad budgeting on the father's part, Participant \# 4 went on to say:

That's the kind of stuff that goes on behind the scenes. If you do it right, that student gets through four years of college without feeling much in the way of bumps at all. There's something to be said for that. There's satisfaction even in just knowing that.

\section{Discussion}

While researching ways to get more students to apply for financial aid through the FAFSA, Davidson found, "the most effective means of increasing FAFSA completion is through one-on-one personal assistance" (Davidson, 2013). But, Davidson finds, there is less funding for FAA positions and the financial aid process demands the FAA "spend a number of hours completing paperwork rather than working directly with students" (2013).

Queried FAAs reported the single largest resource constraint to be not having enough counseling staff-100\% reported this shortage at least some of the time - and the most frequently identified culprit: greater compliance workload (National Association of Student Financial Aid Administrators (NASFAA), 2015). The impact for those institutions that reported a severe shortage of resources was that $70 \%$ of the time, face-to-face counseling was greatly affected, or reduced to meet shortages (National Association of Student Financial Aid Administrators (NASFAA), 2015). Finally, NASFAA reported the top two (of seven) impacts on application processing were those most affiliated with the first year of PPY: "ability to resolve conflicting information" and "ability to verify discretionary data elements." These two accounted for $42 \%$ of the impact of resource shortages on processing (National Association of Student Financial Aid Administrators (NASFAA), 2015). The respondents also indicated the most likely compliance item to be greatly impacted was responding to proposed rulemakings (National Association of Student Financial Aid Administrators (NASFAA), 2015).

This paints a concerning picture. The best way to get students to apply for aid is to offer them one-on-one guidance but many financial aid administrators do not have the time. Nor do they have time to participate in the process which creates the rules which govern their work, creating a vicious cycle.

This study found FAAs were concerned before PPY was deployed about the additional workload resulting from more frequent requests for professional judgments, but no concerns were raised about the intentional re-asking for the same data points. Once PPY was deployed, the volume of professional judgments did not increase as feared but the new and unexpected administrative burden from comment code 399 significantly contributed to the feared increase in workload and hardship for individual students.

And it appears that cycle will continue. In a recent study of core competencies as identified by financial aid administrators, the FAAs surveyed indicated "ability to forecast or identify emerging trends" and "social media application and communication skills" as two of the lowest five in a list of 30 (Woolf \& Martinez, 2013).

\section{Conclusions}

The participants in the study were unable to confirm the findings of either the Advisory Committee on Student Financial Assistance or Boeckenstedt, but instead had experiences similar to what Madzelan (reportedly), Dynarski and Wiederspan, NASFAA, and Kelchen and Jones proposed based on their research. 
It is worth noting that Kelchen and Jones' call for a pilot would have been helpful given that some of the challenges articulated by the participants could have been avoided or at least better mapped.

Case studies on individual student experiences would be helpful for those wishing to understand the edge cases and the impact of the comment code 399 process on students.

The timing of this study was at the very beginning of the DRT being unavailable to students. During the study, the FAAs trusted FSA reports that the DRT would be back up shortly. However, even as of this writing in May 2017, the DRT was still unavailable for FAFSA filers, presumably the neediest filers being those most heavily impacted by the lack of availability to correctly report financial data from the IRS. The impact on the neediest students will be of great interest to the financial aid community.

\section{References}

Advisory Committee on Student Financial Assistance. (1997). Analysis of the office of postsecondary education's prior, prior year (PPY) income proposal: PPY has serious negative implications for equity, burden and program integrity. Briefing paper. Retrieved from Washington, DC: http://files. eric.ed.gov/fulltext/ED411758.pdf

Baker, J. (2016). Eannouncement: Information regarding institutional responsibilities to resolve 2017-2018 comment code 399 conflicting information issues. Retrieved from https://ifap.ed.gov/ eannouncements/102116RegardInstitutionalResponsibilitiesResolve20172018CommentCode399Conflict.html

Boeckenstedt, J. (2015). New FAFSA changes will bring unintended consequences for colleges. Chronicle of Higher Education, 62(4), 17.

Cannon, R., \& Goldrick-Rab, S. (2016). Too late? Too little: The timing of financial aid applications. Retrieved from http://wihopelab.com/publications/ Timing-Financial-Aid-Applications.pdf

Coval, M. M. (2015). Reauthorization ready: How NASFAA influences the higher education policymaking process. Journal of Student Financial Aid, 45(3), 87-91.

Creswell, J. W. (2012). Qualitative inquiry and research design: Choosing among five approaches: Sage publications.

Davidson, J. C. (2013). Increasing FAFSA Completion Rates: Research, Policies and Practices. Journal of Student Financial Aid, 43(1), 4.

Douglas-Gabriel, D. (2017, April 6). Identity thieves may have hacked files of up to 100,000 financial aid applicants. The Washington Post. Retrieved from https://www.washingtonpost.com/news/ grade-point/wp/2017/04/06/identity-thievesmay-have-hacked-files-of-up-to-100000-financial-aid-applicants/?noredirect $=$ on \&utm term=.f7a8fcbc8c14

Dynarski, S. M., \& Wiederspan, M. (2012). Student aid simplification: Looking back and looking ahead. Retrieved from http://www.nber.org/papers/w17834

Federal Student Aid (FSA). (2016a). Dear colleague letter gen-16-14. Retrieved from https://ifap. ed.gov/dpcletters/GEN1614.html.

Federal Student Aid (FSA). (2016b). Sar comment codes and text, 2017-2018. Retrieved from https:// fsadownload.ed.gov/Repository/SARComments1718Aug/2017-2018 SAR CCText 201608.pdf.

Federal Student Aid (FSA). (2017). Irs drt unavailable. Retrieved from https://studentaid.ed.gov/ sa/about/announcements/irs-drt-unavailable

Internal Revenue Service. (2017). Internal Revenue Service (IRS) and U.S. Department of Education Office of Federal Student Aid (FSA) statement about the IRS Data Retrieval Tool (DRT). Retrieved from https://www.irs.gov/newsroom/ internal-revenue-service-irs-and-us-department-of-education-office-of-federal-student-aidfsa-statement-about-the-irs-data-retrieval-tool$\underline{\mathrm{drt}}$

Kelchen, R. (2014). Financial need and aid volatility among students with zero expected family contribution. Journal of Student Financial Aid, 44(3).

Kelchen, R., \& Jones, G. (2015). A simulation of pell grant awards and costs using prior-prior year financial data. Journal of Education Finance, 40(3), 253-272.

National Association of Student Financial Aid Administrators (NASFAA). (2013). A tale of two income years: Comparing prior-prior year and prior-year through pell grant awards. Retrieved from https://www.nasfaa.org/uploads/documents/ ppy report.pdf

National Association of Student Financial Aid Administrators (NASFAA). (2015). 2015 administrative burden survey. Retrieved from https:// www.nasfaa.org/uploads/documents/ektron/f5fdae89-a23f-4572-9724-15e5a9f614d2/0d73bf4cd48a43a6a9414b6ec1a6ab9d2.pdf

National Association of Student Financial Aid Administrators. (2016). 2016 NASFAA benchmarking report. Retrieved from https://www.nasfaa. org/uploads/documents/2016 benchmarking report.pdf

National Association of Student Financial Aid Administrators. (2017). Verification woes top list of DRT concerns in recent nasfaa member poll. Retrieved from https://www.nasfaa.org/news- 
item/11883/Verification Woes Top List of DRT Concerns in Recent NASFAA Member Poll

Polkinghorne, D. E. (1989) Existential-phenomenological perspectives in psychology (pp. 41-60): Springer.

The White House. (2015). Fact sheet: The president's plan for early financial aid: Improving college choice and helping more americans pay for college. Retrieved from https://www.whitehouse. gov/the-press-office/2015/09/14/fact-sheet-president $\% \mathrm{E} 2 \% 80 \% 99$ s-plan-early-financial-aid-improving-college-choice
Woolf, N., \& Martinez, M. (2013). A financial aid competency model for professional development. Journal of Student Financial Aid, 43(2), 3.

\section{Review}

This article was accepted under the constructive peer review option. For futher details, see the descriptions at:

http://mumabusinessreview.org/peer-review-options/

\section{Author}

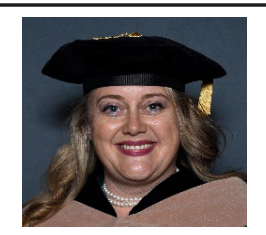

Valerie A. Mockus is the president of a financial aid software consulting firm. She has consulted in the United States with approximately 200 colleges and universities as well as multiple state, vendor, and k-12 organizations. Mockus earned her BA in women's studies at Denison University, her MBA at Saint Francis University in Loretto, Pennsylvania, and her Doctor of Business Administration at University of South Florida. 


\section{Appendix: FAFSA Application}

July 1, 2017 - June 30, 2018
Federal Student Aid $\mid$ proun soonsoror.

FAFSA

FREE APPLICATION for FEDERAL STUDENT AID

Step One (Student): For questions 1-31, leave any questions that do not apply to you (the student) blank. OMB * 1845-0001 Your full name (exactly as it appears on your Social Security card) if your name has a suffix, such as $\mathrm{t}$. or IIt, include a space between your last name and suffix.

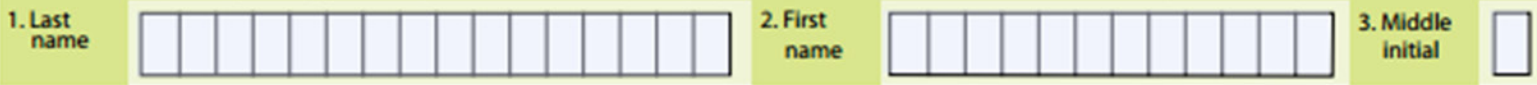

Your permanent mailing address

4. Number and street (include apt. number)

5. City (and country if not U.S.)

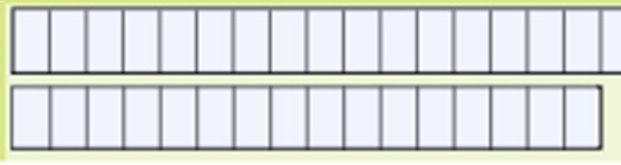

8. Your Social Security Number See Notes page 9.
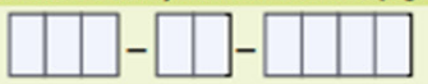

9. Your date
of birth

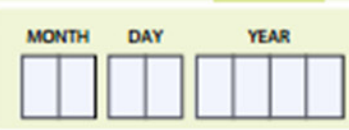

6. State
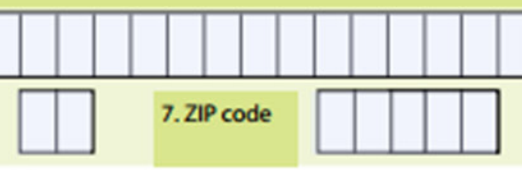

Your driver's license number and driver's license state (if you have one)

11. Driver's license

number

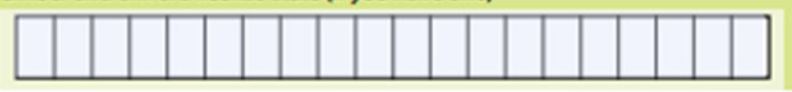

12. Driver's license state

13. Your e-mail address. If you provide your e-mail address, we will communicate with you electronically. For example, when your FAFSA has been processed, you will b notified by e-mail. Your e-mail address will also be shared with your state and the colleges listed on your FAFSA to allow them to communicate with you. If you do not have an e-mail address, leave this field blank.

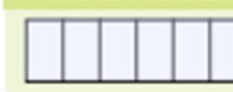

14. Are you a U.S. citizen?

Mark only one.

See Notes page 9.

16. What is your marital status as of today? See Notes page 9.

18. What is your
state of legal residence?

21. Are you male or female?

See Notes page 9. (1)

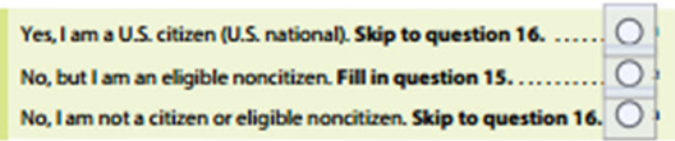

\begin{tabular}{l|l|} 
I am single............ $\mathrm{O}$, & I am separated............ \\
I am married/remarried $\mathrm{O}$, & $\mathrm{O}$
\end{tabular}

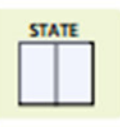

\section{Did you become a legal resident of this state} before January 1, 2012?
10. Your telephone number

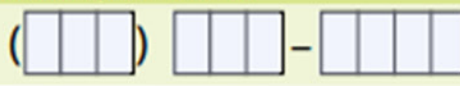

22. If female, skip to question 23. Most male students must register with the Selective Service System to recelve federal aid. If you are male, age 18-25 and Register me $\mathrm{O}$. not registered, fill in the circle and we will register you. See Notes page 9.

\section{Alien Registration Number}

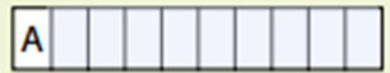

17. Month and year you were married, remarried, separated, divorced or widowed. See Notes page 9.

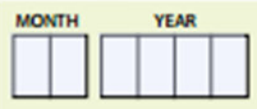

20. If the answer to question 19 is "No," give month and year you became a give month and year you beca
legal resident of that state.

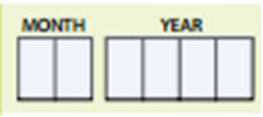

23. Have you been convicted for the possession or sale of illegal drugs for an offense that occurred while you were receiving federal student aid (such as grants, work-study, or loans)?

Answer "No" if you have never received federal student aid or if you have never had a drug conviction for an offense that occurred while receiving federal student aid. If you have a drug conviction for an offense that occurred while you were receiving federal student aid, answer Yes," but complete and submit this application, and we will mail you a worksheet to help you determine if your conviction affects your eligibility for aid. If you are unsure how to answer this question call 1-800-433-3243 for help.

Some states and colleges offer aid based on the level of schooling your parents completed.

24. Highest school completed by Parent 1

25. Highest school completed by Parent 2

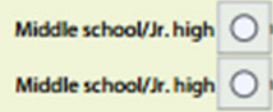

High school $\mathrm{O}$

High school $\mathrm{O}$

College or beyond $\mathrm{O}$, Other/unknown $\mathrm{O}$.

College or beyond $\mathrm{O}$, Other/unknown $\mathrm{O}$.

26. What will your high school completion status be when you begin college in the 2017-2018 school year?

High school diploma. Answer question 27.

General Educational Development (GED) certificate or state certificate. Skip to question 28.

Homeschooled. Skip to question 28.

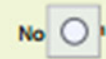

Yes $\mathrm{O}$,

or Help - wwwStudentAid.gov/completefafsa

Page 3

None of the above. Skip to question 28

Step One CONTINUES on Page 
27. What is the name of the high school where you received or will receive your high school diploma? Enter the complete high school name, and the city and state where the high school is located.
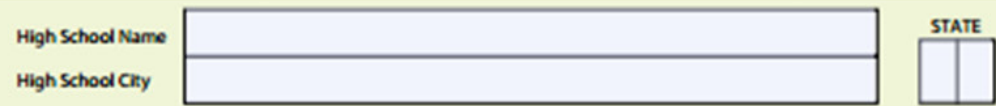

30. What degree or certificate will you be working on when you begin the

29. What will your college grade level be when you begin the 2017-2018 school year?

Never attended college and 1st year undergraduate .

Attended college before and 1st year undergraduate

2nd year undergraduate/sophomore

3rd year undergraduate/junior

4th year undergraduate/senior

Sth year/other undergraduate.

1st year graduate/professional

Continuing graduate/professional or beyond

31. Are you interested in being considered for work-study?

Answer questions 32-58 about yourself (the student). If you were never married, or are separated,

Step Two (Student): divorced or widowed and are not remarried, answer only about yourself. If you are married or remarried as of today, include information about your spouse.

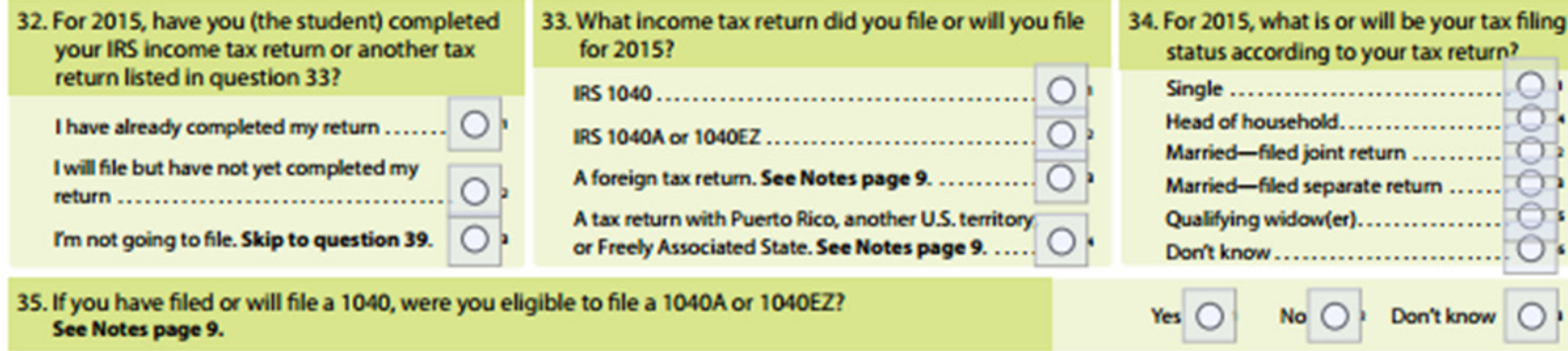

For questions 36-45, if the answer is zero or the question does not apply to you, enter 0 . Report whole dollar amounts with no cents.

36. What was your (and spouse's) adjusted gross income for 2015? Adjusted gross income is on IRS Form 1040-line 37; 1040A-line 21; or 1040EZ-line 4.

37. Enter your (and spouse's) income tax for 2015. Income tax amount is on IRS Form 1040-line 56 minus line 46; $1040 A$-line 28 minus line 36 ; or $1040 E Z$-line 10.

38. Enter your (and spouse's) exemptions for 2015. Exemptions are on IRS Form 1040-line 6d or Form 1040A-line 6d. For form 1040EZ, see Notes page 9.

Questions 39 and 40 ask about earnings (wages, salaries, tips, etc) in 2015. Answer the questions whether or not a tax return was filed. This information may be on the W-2 forms or on the tax return selected in question 33: IRS Form 1040-lines 7+12+18+ Box 14 (Code A) of IRS Schedule K-1 (Form 1065); $1040 \mathrm{~A}$-line 7; or 1040EZ-line 1. If any individual eaming item is negative, do not include that item in your calculation.

39. How much did you eam from working in 2015 ?

40. How much did your spouse earn from working in 2015 ?

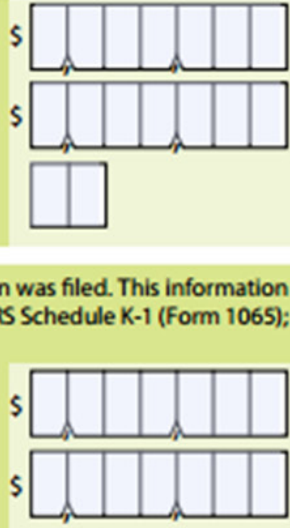

41. As of today, what is your (and spouse's) total current balance of cash, savings, and checking accounts? Don't include student financial aid.

\section{$\$$}

42. As of today, what is the net worth of your (and spouse's) investments, including real estate? Don't include the home you live in. See Notes page 9.

43. As of today, what is the net worth of your (and spouse's) current businesses and/or investment farms? Don't include a family farm or family business with 100 or fewer full-time $\alpha$ full-time equivalent employees. See Notes page 9.

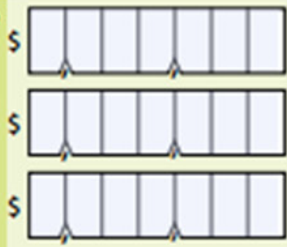

For Help - 1-800-433-3243

Page 4

Step Two CONTINUES on Page 5 

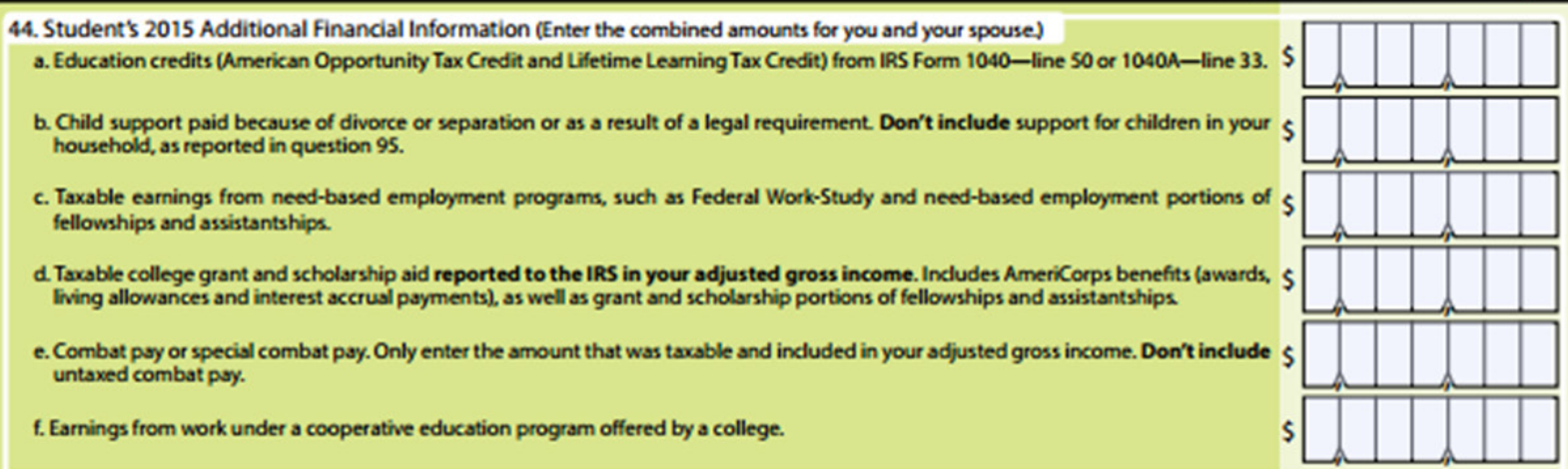

45. Student's 2015 Untaxed Income (Enter the combined amounts for you and your spouse.)

a. Payments to tax-deferred pension and retirement savings plans (paid directly or withheld from earnings), including, but not limited ta, $S$ amounts reported on the W-2 forms in Boxes 12a through 12d, codes D, E, F, G, H and S. Don't include amounts reported in code DD (employer contributions toward employee health benefits).

b. IRA deductions and payments to self-employed SEP, SIMPLE, Keogh and other qualified plans from IRS Form $1040-$ line $28+$ line 32 S or $1040 \mathrm{~A}-$ line 17.

c. Child support received for any of your children. Don't include foster care or adoption poyments.

d. Tax exempt interest income from IRS Form 1040-line $8 \mathrm{~b}$ or $1040 \mathrm{~A}$-line $8 \mathrm{~b}$.

e. Untaxed portions of IRA distributions from IRS Form 1040-lines (15a minus 15b) or 1040A-lines (11 a minus 11b). Exclude rollovers. If negative, enter a zero here.

f. Untaxed portions of pensions from IRS Form 1040-lines (16a minus 16b) or 1040A-lines (12a minus 12b). Exclude rollovers. If negative, enter a zero here.

9. Housing, food and other living allowances paid to members of the military, clergy and others fincluding cash pryments and cash value of benefits). Don't include the value of on-base military housing or the value of a basic military allowance for housing

h. Veterans noneducation benefits, such as Disability, Death Pension, or Dependency \& Indemnity Compensation (DIC) and/or VA Educational Work-Study allowances.

i. Other untaxed income not reported in items 45 a through $45 \mathrm{~h}$, such as workers' compensation disability benefits, etc. Also include the untaxed portions of health savings accounts from IRS Form 1040-line 25. Don't include extended foster care benefits, student aid, earned income credit, additional child tax credit, welfare payments, untaxed Social Security benefits Supplemental Security Income, Workforce Innovation and Opportunity Act educational benefits, on-base military housing or a military housing allowance, combat pay, benefits from flexible spending arrangements (e.g. cafeteria plans), foreign income exclusion or credit for federal tax on special fuels.

j. Money received, or paid on your behalf ( $\mathrm{eg}$. bills), not reported elbewhere on this form. This includes money that you received from a parent or other person whose financial information is not reported on this form and that is not part of a legal child support agreement. See Notes page 9.

Step Three (Student): Answer the questions in this step to determine if you will need to provide parental information. Once you answer "Yes" to any of the questions in this step, skip Step Four and go to Step Five on page 8.

46. Were you born before lanuary 1, 1994?

47. As of today, are you married? (Also answer "Yes" if you are separated but not divorced.)

48. At the beginning of the 2017-2018 school year, will you be working on a master's or doctorate program (such as an MA

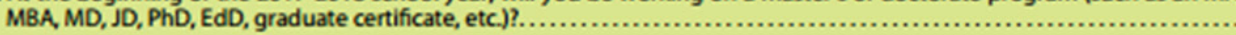

49. Are you currently serving on active duty in the U.S. Armed Forces for purposes other than training? See Notes page 9. ...

50. Are you a veteran of the U.S. Armed Forces? See Notes page 9.

51. Do you now have or will you have children who will receive more than half of their support from you between July 1, 2017 and June 30,2018 ?.

52. Do you have dependents (other than your children or spouse) who live with you and who receive more than half of their

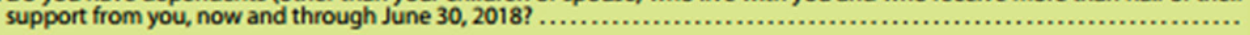

53. At any time since you tumed age 13, were both your parents deceased, were you in foster care or were you a dependent

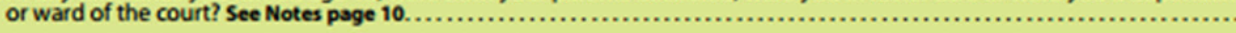

54. As determined by a court in your state of legal residence, are you or were you an emancipated minor? See Notes page 10. ..

55. Does someone other than your parent or stepparent have legal guardianship of you, as determined by a court in your state of legal residence? See Notes page 10.

56. At any time on or after July 1, 2016, did your high school or school district homeless liaison determine that you were an unaccompanied youth who was homeless or were self-supporting and at risk of being homeless? See Notes page 10......

57. At any time on or after July 1, 2016, did the director of an emergency shelter or transitional housing program funded by the U.S. Department of Housing and Urban Development determine that you were an unaccompanied youth who was homeless or were self-supporting and at risk of being homeless? See Notes page 10. .................................. 58. At any time on or after July 1,2016, did the director of a runaway or homeless youth basic center or transitional living
program determine that you were an unaccompanied youth who was homeless or were self-supporting and at risk of

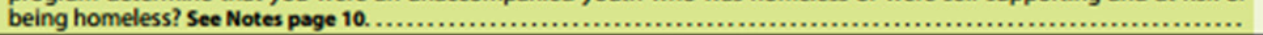

For Help - wmwStudentAid.gov/completefafsa Page 5

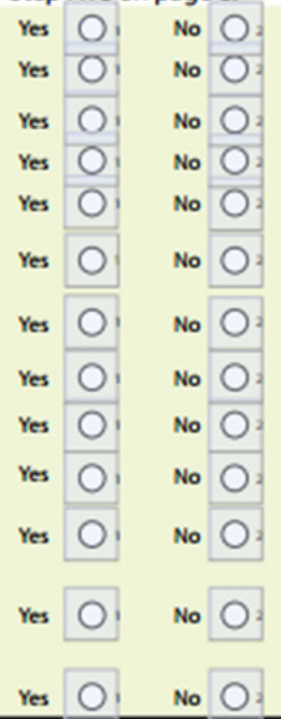

Form CONTINUES on Page 6 
If you (the student) answered "No" to every question in Step Three, go to Step Four.

If you answered "Yes" to any question in Step Three, skip Step Four and go to Step Five on page 8.

(Health professions and law school students: Your college may require you to complete Step Four even if you answered Yes" to any Step Three question).

If you believe that you are unable to provide parental information, see Notes page 10.

Step Four (Parent): Complete this step if you (the student) answered "No" to all questions in Step Three.

Answer all the questions in Step Four even if you do not live with your legal parents (biological, sdoptive, or as determined by the state lfor example, if the parent is listed on the birth certificate]. Grandparents, foster parents, legal guardians, widowed stepparents, aunts, uncles, and siblings are not considered parents on this form unless they hove legally adopted you. If your legal parents are married to each other, or are not married to each other and live together, answer the questions about both of them

59. As of today, what is the marital status of your legal parents?

Never married.

.

Unmarried and both parents living

60. Month and year

they were married,

remarried, separated,

divorced or widowed.

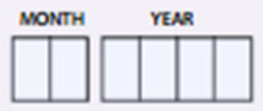

What are the Social Security Numbers, names and dates of birth of the parents reporting information on this form?

If your parent does not have a Social Security Number, you must enter 000-00-0000. If the name includes a suffix, such as $\mathrm{f}$. or III, include a space between the last name and suffix. Enter two digits for each day and month (e.g, for May 31, enter 0531 ).

Questions 61.64 are for Pareme 1 Gather/mother/ftoparent?

61. socul secuntrounes
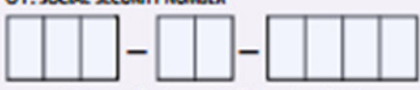

62. LASTNAME, aND

63. FoST wMAL 64. DATE of BaTM

Questions $65-68$ are for Parem: 2 father/mother/stepparent

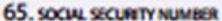

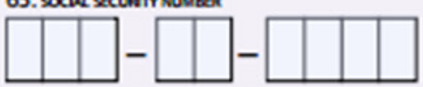

66. ustrume, nND

67. Fast wmat 68. Date of arth

69. Your parents' e-mail address. If you provide your parents' e-mail address, we will let them know your FAFSA has been processed. This e-mail address will also be shared with your state and the colleges listed on your FAFSA to allow them to electronically communicate with your parents.

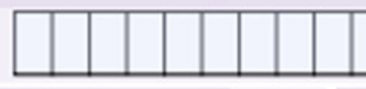

70. What is your parents' state of legal residence?
STATE

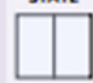

71. Did your parents become legal residents of this state before January 1, 2012?
Yes $\mathrm{O}$, No $\mathrm{O}_{2}$
72. If the answer to question 71 is " $\mathrm{No}$," give the month and year legal residency began for the parent who has lived in the state the longest.

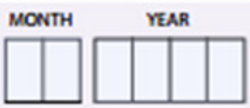

73. How many people are in your parents' household?

Include:

- yourself, even if you don't live with your parents,

- your parents,

your parents' other children (even if they do not live with your parents) if (a) your parents will provide more than half of their support

between July 1, 2017 and June 30, 2018, or (b) the children could answer "No" to every question in Step Three on page S of this form and

- other people if they now live with your parents, your parents provide more than half of their support and your parents will continue to

provide more than half of their support between July 1,2017 and June 30, 2018.

74. How many people in your parents' household (from question 73) will be college students between July 1, 2017 and June 30, 2018 ? Always count yourself as a college student. Do not include your parents. Do not include siblings who are in U.S. military service academies. You may include others only if they will attend, at least half-time in 2017-2018, a program that leads to a college degree or certificate.

At any time during 2015 or 2016, did you your parents, or anyone in your parents' household (from question 73) recehve benefits from any of the federal programs listed? Mark all that apply. Answering these questions will NOT reduce eligiblity for student aid or these programs. TANF has different names in many states Call 1-800-433-3243 to find out the name of your state's program. If you, your parents, or amyone in your household receives any of these benefits after filing the FAFSA but before December 31, 2016, you must update your response by logging in to www.fafsa.gov and selecting "Make FAFSA Corrections" Supplemental $\bigcirc$ Nutrition Assistance $O$ Price School $O$ for Needy Families Security income (SSI) Program (SNAP)

Lunch (TANF)

79. Special Supplemental Nutrition Program for Women, Infants, and Children (WMC)

If your answer to question 59 was "Unmarried and both parents living together," contact 1-800-433-3243 for assistance with answering questions 80-94.

80 . For 2015, have your parents completed their IRS income tax retum or another tax return listed in question 81 ?

My parents have already completed their return.

My parents will file but have not yet completed their return.......................................

My parents are not going to file.

Skip to question 88 .

83. If your parents have filed or will file a 1040 were they eligible to file a $1040 \mathrm{~A}$ or $1040 \mathrm{EZ}$ ? See Notes page 9.

For Help - 1-800-433-3243
81. What income tax return did your parents file or will they file for 2015?

IRS 1040 .

IRS 1040A or 1040EZ

A foreign tax return. See Notes page 9...

A tax return with Puerto Rico, another US

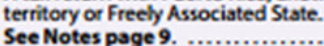

Yes $\mathrm{O}$
No $\mathrm{O}$

Don't know $\mathrm{O}$ :

84. As of today, is either of your parents a dislocated worker? See Notes page 10.
82. For 2015, what is or will be your parents' tax filing status according to their tax return?

Single.

Head of household. Married-filed joint return Married-filed separate return ....... Qualifying widow(er)................. $\mathrm{O}$ s Dont know ............................ $\mathrm{O}$ "

$$
\text { Yes } \mathrm{O}
$$$$
\text { No }()
$$

Don't know $\mathrm{O}$ 
For questions 85-94, if the answer is zero or the question does not apply, enter 0. Report whole dollar amounts with no cents.

85. What was your parents' adjusted gross income for 2015? Adjusted gross income is on IRS form 1040-line 37; $1040 \mathrm{~A}$-line 21 ; or $1040 \mathrm{EZ}$-line 4.

86. Enter your parents' income tax for 2015. Income tax amount is on IRS form 1040-line 56 minus line 46: $1040 \mathrm{~A}$-line 28 minus line 36 ; or $1040 \mathrm{EZ}$-line 10.

87. Enter your parents' exemptions for 2015. Exemptions are on IRS form 1040-line 6d or on form 1040A-line 6d. For Form 1040EZ, see Notes page 9.

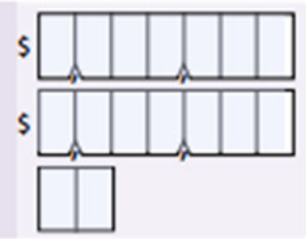

Ouestions 88 and 89 ask about eamings (wages, salaries, tips, etc) in 2015. Answer the questions whether or not a tax retum was filed, This information may be on the W-2 forms or on the tax return selected in question 81: IRS Form 1040-lines 7+12+18+ Box 14 (Code A) of IRS Schedule K-1 (Form 1065): 1040A-line 7; or 1040EZ-line 1. If any individual earning item is negative, do not include that item in your cakulation. Report the information for the parent listed in questions $61-64$ in question 88 and the information for the parent listed in questions $65-68$ in question 89.

88. How much did Parent 1 (father/mother/stepparent) earn from working in 2015?

89. How much did Parent 2 (father/mother/stepparent) earn from working in 2015?

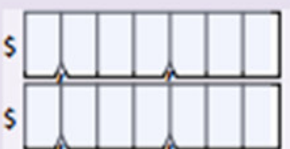

90. As of today, what is your parents' total current balance of cash, savings, and checking accounts? Don't include student financial aid.

91. As of today, what is the net worth of your parents' investments, including real estate? Don't include the home in which your parents live. See Notes page 9.

92. As of today, what is the net worth of your parents' current businesses and/or investment farms? Don't include a family farm or family business with 100 or fewer full-time or full-time equivalent employees. See Notes page 9.

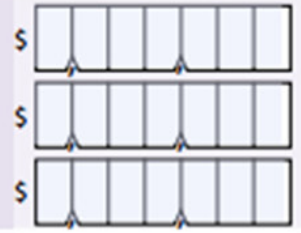

93. Parents' 2015 Additional Financial Information (Enter the amounts for your parent(s].)

a. Education credits (American Opportunity Tax Credit and Lifetime Leaming Tax Credit) from IRS Form 1040-line 50 or $1040 \mathrm{~A}-\$$ line 33.

b. Child support paid because of divorce or separation or as a result of a legal requirement. Don't include support for children in your parents' household, as reported in question 73.

c. Your parents' taxable earnings from need-based employment programs, such as Federal Work-Study and need-based employment portions of fellowships and assistantships.

d. Your parents' taxable college grant and scholarship sid reported to the IRS in your parents' adjusted gross income. Includes Americorps benefits (awards, living allowances and interest accrual payments), as well as grant and scholarship portions of fellowships $\$$ and assistantships.

e. Combat pay or special combat pay. Only enter the amount that was taxable and included in your parents' adjusted gross income. Don't include untaxed combat pay.

f. Eamings from work under a cooperative education program offered by a college.

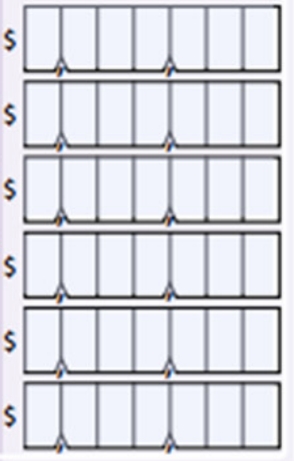

94. Parents' 2015 Untaxed Income (Enter the amounts for your parent[s])

a. Payments to tax-deferred pension and retirement savings plans (poid directly or withheld from earnings), including, but not limited to, $S$ amounts reported on the W-2 forms in Boxes 12a through 12d, codes D, E, F, G, H and S. Don't include amounts reported in code DD (employer contributions toward employee health benefits)

b. IRA deductions and payments to self-employed SEP, SIMPLE, Keogh and other qualified plans from IRS Form 1040-line $28+$ line 32 or S 1040 A-line 17.

c. Child support received for any of your parents' children. Don't include foster care or adoption payments.
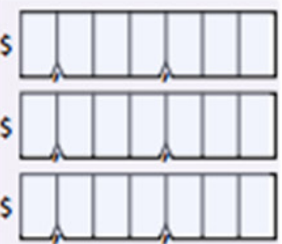

d. Tax exempt interest income from IRS Form 1040 -line $8 \mathrm{~b}$ or $1040 \mathrm{~A}-$ line $8 \mathrm{~b}$.

$\$$

e. Untaxed portions of IRA distributions from IRS Form 1040-lines (15a minus 15b) or 1040A-lines (11a minus 11b). Exclude rollovers. If negative, enter a zero here.

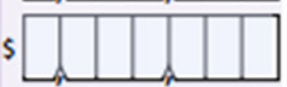

f. Untaxed portions of pensions from IRS Form 1040-lines (16a minus 16b) or 1040A-lines (12a minus 12b). Exclude rollovers. If negative, enter a zero here.

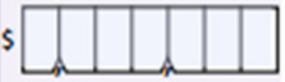

9. Housing, food and other living allowances paid to members of the military, clergy and others (including cash payments and cash value $S$ of benefits). Don't include the value of on-base military housing or the value of a basic military allowance for housing.

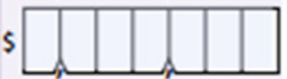

h. Veterans noneducation benefits, such as Disability, Death Pension, or Dependency \& Indemnity Compensation (DIC) and/or VA Educational Work-Study allowances.

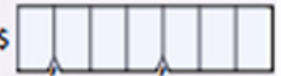

i. Other untaxed income not reported in items 94 a through $94 \mathrm{~h}$, such as workers' compensation, disability benefits, etc. Also include the untaxed portions of health savings accounts from IRS Form 1040-line 25. Don't include extended foster care benefits, student aid, earned income credit additional child tax credit welfare payments, untared Social Security benefits, Supplemental Security Income, Workforce Inne cration and Opportunity Act education lo pasts benefits from flexible spending arrangements (e.g. cafeteria plans), foreign income exclusion or credit for federal tax on special fuels.

For Help - wmwStudentAid.gov/completefafsa 
Step Five (Student): Complete this step only if you (the student) answered "Yes" to any questions in Step Three.

95. How many people are in your household?

Include:

- yourself (and your spouse).

- your children, if you will provide more than half of their support between July 1,2017 and June 30, 2018, even if they do not live with you, and

other people if they now live with you, you provide more than half of their support and you will continue to provide more than half of their support between July 1, 2017 and June 30, 2018.

96. How many people in your (and your spouse's) household (from question 95) will be college students between July 1, 2017 and June 30, 2018? Aways count yourself as a college student. Do not include family members who are in US. military service academies. Include others only if they will attend, at least half-time in 2017-2018, a program that leads to a college degree or certificate.

At any time during $2015 \propto 2016$, did you (or your spouse) or anyone in your household (from question 95 ) recelve benefits from any of the federal programs listed? Mark all that apply. Answering these questions will NOT reduce eligbility for student aid or these programs. TANF has different names in many states. Call 1-800-433-3243 to find out the name of your state's program. If you (or your spouse) or anyone in your household receives any of these benefits after fling the FAFSA but before December 31, 2016, you must update your response by logging in to www.fafsa.gov and selecting "Make FAFSA Corrections."

97. Medicaid or

Security Income (SSi)

98. Supplemental

Nutrition Assistance
Program (SNAP)

99. Free or Reduced

Price School

Lunch

100. Temporary Assistance
for Needy Families (TANF)
101. Special Supplemental Nutrition Program for Women, Infants, $\mathrm{O}$ and Children (WIC)

No $\mathrm{O}$, Don'tknow

102. As of today, are you (or your spouse) a dislocated worker? See Notes page 10.

Step Six (Student): Indicate which colleges you want to receive your FAFSA information.

Enter the six-digit federal school code and your housing plans for each college or school you wish to receive your FAFSA information. You can find the school codes at www.fafsa.gov or by calling 1-800-433-3243. If you cannot obtain a code, write in the complete name, address, city and state of the college. All of the information you included on your FAFSA, with the exception of the list of colleges, will be sent to each of the colleges you listed. In addition, all of your FAFSA information, including the list of colleges, will be sent to your state student grant agency. For federal student aid purposes, it does not matter in what order you list your selected schools. However, the order in which you list schools may affect your eligibility for state aid. Check with you state grant agency for more information. To find out how to have more colleges receive your FAFSA information, read What is the FAFSA? on page 2.

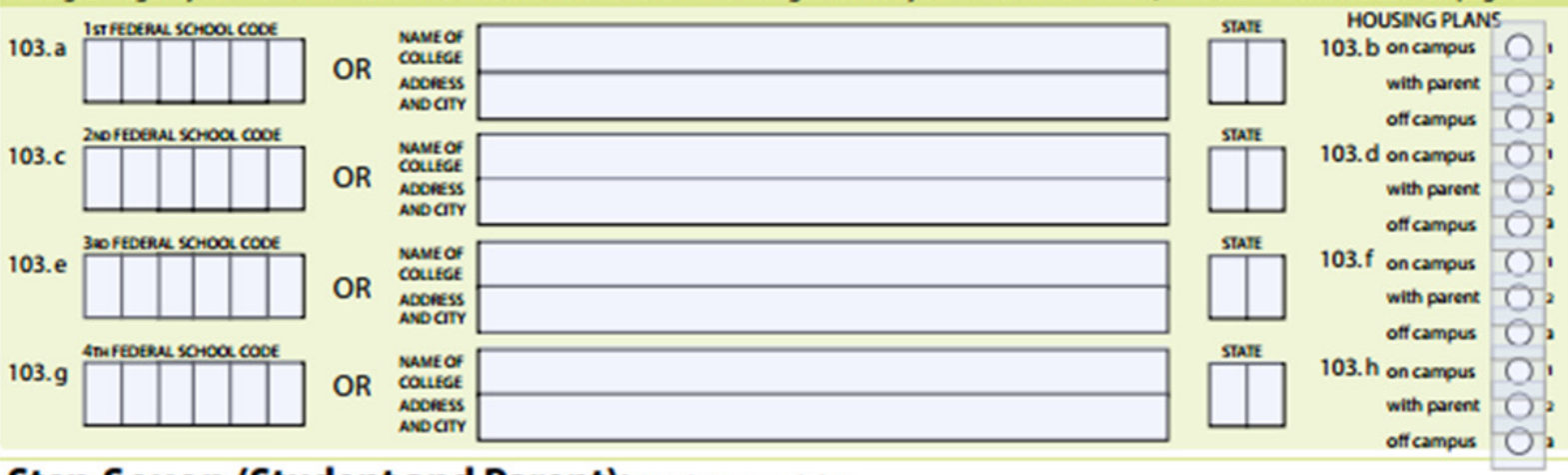

Step Seven (Student and Parent): Read, sign and date.

If you are the student, by signing this application you certify that you (1) will use federal and/or state student financial aid only to pay the cost of attending an institution of higher education, (2) are not in default on a federal student loan or have made satisfactory arrangements to repay it, (3) do not owe money back on a federal student grant or hove made satisfactory arrangements to repay it, (4)
will notify your college if you default on a federal student loan and (5) will not receive a Federal Pell Grant from more than one college for the same period of time.

If you are the parent or the student, by signing this application you certify that all of the information you provided is true and complete to the best of your knowledge and you agree, if asked, to provide information that will verify the accuracy of your completed form. This information may include US. or state income tax forms that you filed or are required to file. Also, you certify that you understand that the Secretary of Education has the authority to verify information reported on this application with the Internal Revenue Service and other federal agencies. If you sign any document related to the federal student aid programs electronically using a personal identification number (PIN), username and password, and/or any other credential you certify that you are the person identified by that PIN, username and password, and/or other credential, and have no: disclosed that PIN, usemame and password, and/or other credential to anyone else. if you purposely give false or misleading information, you may be fined up to $\$ 20,000$, sent to prison, or both.

104. Date this form was completed

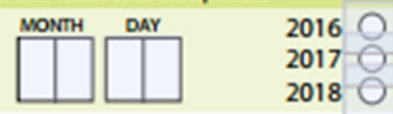

105. Student (Sign below)

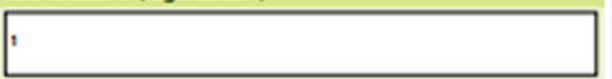

Parent (A parent from Step four sign below.)

2

COLLEGE USE ONLY FEDERN SCHOOL COOE

D/O O. Pomedew $\mathrm{O}$.

fMA Signature

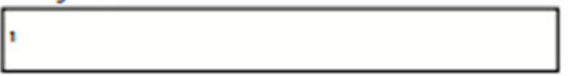

DATAEnTRY OP O. OL OE 
Notes for question 8 (page 3 )

Enter your Social Security Number (SSN) as it appears on your Social Security card. If you are a resident of the Freely Associated States (i.e, the Republic of Palau, the Republic of the Marshall islands, or the Federated States of Micronesia) and were issued an identification number beginning with " $666^{*}$ when submitting a FAFSA previously, enter that number here. If you are a first-time applicant from the Freely Associated States, enter "666" in the first three boxes of the SSN field and leave the remaining six positions blank and we will create an identification number to be used for federal student aid purposes.

\section{Notes for questions 14 and 15 (page 3)}

If you are an eligible noncitizen, write in your eight- or nine-digit Alien Registration Number. Generally, you are an eligible noncitizen if you are (1) a permanent U.S. resident with a Permanent Resident Card (1-551): (2) a conditional permanent resident with a Conditional Green Card (1-551C): (3) the holder of an Arrival-Departure Record (1-94) from the Department of Homeland Security showing any one of the following designations: "Refugee," "Asylum Granted," "Parolee" (1-94 confirms that you were paroled for a minimum of one year and status has not expired). T-Visa holder (T-1, T-2, T-3, etc.) $\propto$ " "Cuban-Haitian Entrant;" or (4) the holder of a valid certification or eligibility letter from the Department of Health and Human Services showing a designation of "Victim of human trafficking."

If you are in the U.S. and have been granted Deferred Action for Childhood Arrivals (DACA), an F1 or F2 student visa, a J1 or J2 exchange visitor visa, or a $\mathrm{G}$ series visa (pertaining to intemational organizations), select "No, 1 am not a citizen or eligible noncitizen." You will not be eligible for federal student aid. If you have a Social Security Number but are not a citizen or an eligible noncitizen, including if you have been granted DACA, you should still complete the FAFSA because you may be eligible for state or college aid.

\section{Notes for questions 16 and 17 (page 3)}

Report your marital status as of the date you sign your FAFSA. If your marital status changes after you sign your FAFSA, check with the financial aid office at the college.

\section{Notes for questions 21 and 22 (page 3)}

To be eligible for federal student aid, male citizens and male immigrants residing in the U.S. aged 18 through 25 are required to register with the Selective Service System, with limited exceptions. This requirement applies to any person assigned the sex of male at birth. The Selective Service System and the registration requirement for males preserve America's ability to provide resources in an emergency to the U.S. Armed Forces (Army, Navy, Air Force, Marines, or Coast Guard). For more information about the Selective Service System, visit www.sss.gov. Forms are available at your local U.S. Post Office.

\section{Notes for questions 33 (page 4)}

\section{and 81 (page 6)}

If you filed or will file a foreign tax return, a tax retum with Puerto Rico, another U.S. territory (e.g. Guam, American Samoa, the U.S. Virgin Islands, Swain's Island or the Northern Marianas Islands) or one of the Freely Assodated States, use the information from that return to fill out this form. If you filed a foreign return, convert all monetary units to U.S. dollars, using the published exchange rate in effect for the date nearest to today's date. To view the daily exchange rates, go to www.federalreserve.gov/releases/ $\mathrm{h} 10 /$ current.

\section{Notes for questions 35 (page 4)}

\section{and 83 (page 6)}

In general, a person is eligible to file a 1040A or 1040EZ if he or she makes less than $\$ 100,000$, does not itemize deductions, does not receive income from his or her own business or farm and does not receive alimony. A person is not eligible to file a 1040A or 1040EZ if he or she makes $\$ 100,000$ or more, itemizes deductions, receives income from his or her own business or farm, is self-employed, receives alimony or is required to file Schedule D for capital gains. If you filed a 1040 only to claim the American Opportunity Tax Credit or Lifetime Learning Tax Credit, and you would have otherwise been eligible to file a 1040A or 1040EZ, answer "Yes" to this question. If you filed a 1040 and were not required to file a tax return, answer "Yes" to this question.

\section{Notes for questions 38 (page 4)}

and 87 (page 7) - Notes for those who filed a 1040EZ

On the 1040EZ, if a person didn't check either box on line 5, enter 01 if he or she is single or has never been married, or 02 if he or she is married. If a person checked either the "you" or "spouse" box on line 5, use 1040EZ worksheet line $\mathrm{F}$ to determine the number of exemptions ( $\$ 4,000$ equals one exemption).

\section{Notes for questions 42 and 43 (page 4), 45j (page 5),} and 91 and 92 (page 7)

Net worth means the current value, as of today, of investments, businesses, and/or investment farms, minus debts related to those same investments, businesses, and/or investment farms. When calculating net worth use 0 for investments or properties with a negative value.

Investments include real estate (do not include the home in which you live), rental property (includes a unit within a family home that has its own entrance, kitchen, and bath rented to someone other than a family member), trust funds, UGMA and UTMA accounts, money market funds, mutual funds, certificates of deposit, stocks, stock options, bonds, other securities, installment and land sale contracts (including mortgages held), commodities, etc.

Investments also include qualified educational benefits $\alpha$ education savings accounts (e.g. Coverdell savings accounts, 529 college savings plans and the refund value of $\mathbf{5 2 9}$ prepaid tuition plans). For a student who does not report parental information, the accounts owned by the student (and/or the student's spouse) are reported as student investments in question 42. For a student who must report parental information, the accounts are reported as parental investments in question 91 , including all accounts owmed by the student and all accounts owned by the parents for any member of the household.

Money received, or paid on your behalf, also includes distributions to you (the student beneficiary) from a 529 plan that is owned by someone other than you or your parents (such as your grandparents, aunts, uncles, and non-custodial parents). You must include these distribution amounts in question 45 j.

Investments do not include the home you live in, the value of life insurance, retirement plans $(401[\mathrm{k})$ plans, pension funds, annuities, noneducation IRAs, Keogh plans, etc.) or cash, savings and checking accounts already reported in questions 41 and 90 .

Investments also do not include UGMA and UTMA accounts for which you are the custodian, but not the owner.

Investment value means the current balance or market value of these investments as of today. Investment debt means only those debts that are related to the investments.

Business and/or investment farm value includes the market value of land, buildings, machinery, equipment, inventory, etc. Business and/or investment farm debt means only those debts for which the business or investment farm was used as collateral.

Business value does not include the value of a small business if your family owns and controls more than 50 percent of the business and the business has 100 or fewer full-time or full-time equivalent employees. For small business value, your family includes (1) persons directly related to you, such as a parent, sister or cousin, or (2) persons who are or were related to you by marriage, such as a spouse, stepparent or sister-in-law.

Investment farm value does not include the value of a family farm that you (your spouse and/or your parents) live on and operate.

\section{Notes for question 49 (page 5)}

Answer "Yes" if you are currently serving in the U.S. Armed forces or are a National Guard or Reserves enlistee who is on active duty for other than state or training purposes.

Answer "No" if you are a National Guard or Reserves enlistee who is on active duty for state or training purposes.

\section{Notes for question $\mathbf{5 0}$ (page 5)}

Answer "Yes" (you are a veteran) if you (1) have engaged in active duty (including basic training) in the U.S. Armed Forces, or are a National Guard or Reserves enlistee who was called to active duty for other than state or training purposes, or were a cadet or midshipman at one of the service academies, and (2) were released under a condition other than dishonorable. Also answer "Yes" if you are not a veteran now but will be one by June 30, 2018.

Answer "No" (you are not a veteran) if you (1) have never engaged in active duty (including basic training) in the U.S. Armed Forces, (2) are currently an ROTC student or a cadet or midshipman at a service academy, (3) are a National Guard or Reserves enlistee activated only for state or training purposes, $\alpha$ (4) were engaged in active duty in the U.S. Armed forces but released under dishonorable conditions.

Also answer "No" if you are currently serving in the U.S. Armed forces and will continue to serve through June $30,2018$.

Page 9 
Notes for question 53 (page 5)

Answer "Yes" if at any time since you turned age 13:

- You had no living parent, even if you are now adopted; or

- You were in foster care, even if you are no longer in foster care today; or

- You were a dependent or ward of the court, even if you are no longer a dependent or ward of the court today. For federal student aid purposes, someone who is incarcerated is not considered a ward of the court.

If you are not sure if you were in foster care, check with your state child welfare agency. You can find that agency's contact information at childwelfare.gov/nfcad.

The financial aid administrator at your school may require you to provide proof that you were in foster care or a dependent or ward of the court.

\section{Notes for questions 54 and 55 (page 5)}

The definition of legal guardianship does not include your parents, even If they were appointed by a court to be your guardians. You are also not considered a legal guardian of yourself.

Answer "Yes" if you can provide a copy of a court's decision that as of today you are an emancipated minor or are in legal guardianship. Also answer 'Yes' if you can provide a copy of a court's decision that you were an emancipated minor or were in legal guardianship immediately before you reached the age of being an adult in your state. The court must be located in your state of legal residence at the time the court's decision was issued.

Answer "No" if you are still a minor and the court decision is no longer in effect or the court decision was not in effect at the time you became an adult. Also answer "No" and contact your school if custody was awarded by the courts and the court papers say"custody" (not "guardianship").

The financial aid administrator at your college may require you to provide proof that you were an emancipated minor or in legal guardianship.

\section{Notes for questions 56-58 (page 5)}

Answer 'Yes' if you received a determination at any time on or after July 1,2016 , that you were an unaccompanied youth who was homeless or at risk of being homeless.

- "Homeless" means lacking fixed, regular and adequate housing. You may be homeless if you are living in shelters, parks, motels, hotels, public spaces, camping grounds, cars, abandoned buildings, or temporarily living with other people because you have nowhere else to go. Also, if you are living in any of these situations and fleeing an abusive parent, you may be considered homeless even if your parent would otherwise provide a place to live.

- "Unaccompanied" means you are not living in the physical custody of your parent or guardian.

- "Youth" means you are 21 years of age or younger or you are still enrolled in high school as of the day you sign this application.

Answer "No" if you are not homeless $\alpha$ at risk of being homeless, or do not have a determination. However, even if you answer "No" to each of questions 56,57 , and 58 , you should contact the financial aid administrator at the college you plan to attend if you are under 24 years of age and are either (1) homeless and unaccompanied or (2) at risk of being homeless, unaccompanied, and providing for your own living expenses - as your college financial aid office can determine that you are "homeless" and are not required to provide parental information.

The financial aid administrator at your college may require you to provide a copy of the determination if you answered 'Yes' to any of these questions.

Notes for students unable to provide parental information on pages 6 and 7

Under very limited circumstances (for example, your parents are incarcerated; you have left home due to an abusive family environment; or you do not know where your parents are and are unable to contact them), you may be able to submit your FAFSA without parental information. If you are unable to provide parental information, skip Steps four and Five, and go to Step Sib. Once you submit your FAFSA without parental data, you must follow up with the financial aid office at the college you plan to attend, in order to complete your FAFSA.

\section{Notes for Step Four, questions 59-94 (pages 6 and 7)}

Review all instructions below to determine who is considered a parent on this form:

- If your parent was never married and does not live with your other legal parent, or if your parent is widowed and not remarried, answer the questions about that parent.

- If your legal parents (biological, adoptive, $\alpha$ as determined by the state [for example, if the parent is listed on the birth certificate]) are not married to each other and live together, select "Unmarried and both parents living together" and provide information about both of them regardless of their gender. Do not include any person who is not married to your parent and who is not a legal or biological parent. Contact 1-800-433-3243 for assistance in completing questions $80-94$, or visit StudentAid.gov/fafsa-parent.

- If your legal parents are married, select "Married or remarried." If your legal parents are divorced but living together, select "Unmarried and both parents Iiving together." If your legal parents are separated but living together, select "Married or remarried," not "Divorced or separated."

- If your parents are divorced or separated, answer the questions about the parent you lived with more during the past 12 months. (If you did not live with one parent more than the other, give answers about the parent who provided more financial support during the past 12 months or during the most recent year that you actually received support from a parent.) If this parent is remarried as of today, answer the questions about that parent and your stepparent.

- If your widowed parent is remarried as of today, answer the questions about that parent and your stepparent.

Notes for questions 84 (page 6)

and 102 (page 8)

In general, a person may be considered a dislocated worker if he or she:

- is receiving unemployment benefits due to being laid off or losing a job and is unlikely to return to a previous occupation;

- has been laid off or received a lay-off notice from a job;

- was self-employed but is now unemployed due to economic conditions or natural disaster; or

- is the spouse of an active duty member of the Armed forces and has experienced a loss of employment because of relocating due to permanent change in duty station; or

- is the spouse of an active duty member of the Armed forces and is unemployed or underemployed, and is experiencing difficulty in obtaining or upgrading employment; or

- is a displaced homemaker. A displaced homemaker is generally a person who previously provided unpaid services to the family (e.g. a stay-at-home mom or dad), is no longer supported by the spouse, is unemployed or underemployed, and is having trouble finding or upgrading employment.

Except for the spouse of an active duty member of the Armed Forces, if a person quits work, generally he or she is not considered a dislocated worker even if, for example, the person is receiving unemployment benefits.

Answer "Yes" to question 84 if your parent is a dislocated worker. Answer "Yes" to question 102 if you or your spouse is a dislocated worker.

Answer "No" to question 84 if your parent is not a dislocated worker. Answer "No" to question 102 if neither you nor your spouse is a dislocated worker.

Answer "Don't know' to question 84 if you are not sure whether your parent is a dislocated worker. Answer "Don't know" to question 102 if you are not sure whether you or your spouse is a dislocated worker. You can contact your financial aid office for assistance in answering these questions.

The financial aid administrator at your college may require you to provide proof that your parent is a dislocated worker, if you answered "Yes" to question 84, or that you or your spouse is a dislocated worker, if you answered "Yes" to question 102. 